\title{
Cardiorenal Syndromes: Advances in Determining Diagnosis, Prognosis, and Therapy
}

Peter A. McCullough ${ }^{1 *}$, James A. Tumlin ${ }^{2}$, Harold Szerlip ${ }^{3}$, Krishnaswami Vijayaraghavan ${ }^{4}$, Sathya Jyothinagaram ${ }^{5}$, John F. Rausch Jr ${ }^{6}$, Bhupinder Singh ${ }^{7}$, Jun Zhang ${ }^{8}$ and Mikhail Kosiborod ${ }^{9}$

${ }^{1}$ Baylor University Medical Center, Baylor Heart and Vascular Institute, Baylor Jack and Jane Hamilton Heart and Vascular Hospital, Dallas, TX, The Heart Hospital, Plano, TX, USA

${ }^{2}$ Internal Medicine/Nephrology, University of Tennessee College Medicine, Southeast Renal Research Institute, Chattanooga, TN, USA

${ }^{3}$ Baylor University Medical Center, Dallas, TX, USA

${ }^{4}$ Scottsdale Cardiovascular Center, Scottsdale, AZ, USA

${ }^{5}$ Banner Good Samaritan Medical Center, Phoenix, AZ, USA

${ }^{6}$ Cigna HealthCare, Clinical Performance and Quality Organization, Phoenix, AZ, USA

${ }^{7}$ Southwest Kidney Institute, Tempe, AZ, USA

${ }^{8}$ Baylor Heart and Vascular Institute, Dallas, TX, USA

${ }^{9}$ Saint Luke's Hospital of Kansas City, Saint Luke's Mid America Heart Institute, University of Missouri-Kansas City, Kansas City, Missouri, USA

\begin{abstract}
The term cardiorenal syndrome (CRS) implies acute or chronic injury to the heart and kidneys that often involves a temporal sequence of disease initiation and progression. The classification of CRS is divided into five subtypes. Types 1 and 2 involve acute and chronic cardiovascular disease (CVD) scenarios leading to acute kidney injury (AKI) or accelerated chronic kidney disease (CKD). Types 3 and 4, describe AKI and CKD, respectively, leading primarily to heart failure, although, it is possible that acute coronary syndromes, stroke, and arrhythmias could be CVD outcomes in these forms of CRS. Finally, CRS type 5 describes a systemic insult to both heart and the kidneys, such as sepsis, where both organs are injured simultaneously in persons with previously normal heart and kidney function at baseline. This manuscript will summarize key issues and future opportunities in challenging patients with CRS. Because most CRS occur in patients with pre-existing myocardial disease or chronic kidney disease, we will emphasize the chronic condition which puts individuals at risk for acute events. In the setting of a hospitalization, acute CRS can occur which have been consistently associated with inpatient complications, longer lengths of intensive care unit and hospital stay, need for renal replacement therapy, rehospitalization and death. While there are several common diagnostic and therapeutic targets for the heart and kidney, there remains considerable opportunity for both in-vitro diagnostics and medicinal therapy to favorably influence the occurrence and natural history of CRS.
\end{abstract}

Keywords:Cardiorenal syndromes; Acute kidney injury; Chronic kidney disease; Heart failure; Biomarkers; Surrogate outcomes; Hospitalization; End-stage renal disease; Mortality

\section{Introduction}

The term cardiorenal syndrome (CRS) implies acute or chronic injury to the heart and kidneys that often involves a temporal sequence of disease initiation and progression. The classification of CRS is divided into five subtypes each of which has complicated and poorly understood pathogenetic factors, yet holding promise for research and clinical opportunities to improve patient outcomes (Figure 1). Types 1 and 2 involve acute and chronic cardiovascular disease (CVD) scenarios leading to acute kidney injury (AKI) or accelerated chronic kidney disease (CKD). Types 3 and 4, describe AKI and CKD, respectively, leading primarily to heart failure, although, it is possible that acute coronary syndromes, stroke, and arrhythmias could be CVD outcomes in these forms of CRS. Finally, CRS type 5 describes a systemic insult to both heart and the kidneys, such as sepsis, where both organs are injured simultaneously in persons with previously normal heart and kidney function at baseline. It has been long-recognized that the most significant predictor of cardiovascular outcomes in coronary atherosclerosis and myocardial disease is baseline renal function as reflected by the serum creatinine, blood urea nitrogen, cystatin- $\mathrm{C}$, calculated creatine clearance, and estimated glomerular filtration rate (eGFR) [1-3]. While it is believed that a considerable amount of the association between decreased renal function and cardiovascular outcomes is due to confounding by older age, diabetes, hypertension, and fragility, there remains considerable variability that is likely explained by pathophysiology that involves both organ systems via organ cross-talk $[4,5]$. Conversely, it has also been well-recognized that a leading cause of mortality among patients with advanced chronic kidney disease (CKD) and end-stage renal disease (ESRD) is cardiovascular disease [6]. Of particular note, patients with significant CKD are more likely to die of cardiovascular disease than reach ESRD and require dialysis. Thus, there has been considerable interest in CRS as an important clinical intersection in which new diagnostic and therapeutic targets may be found. As the majority of acute CRS occur in the setting of pre-existing disease (heart failure or CKD), we will discuss chronic CRS as the set-up for acute CRS.

\section{Chronic Cardiorenal Syndromes}

In the schema of five CRS subtypes, the chronic CRS are Type 2

*Corresponding author: Peter A. McCullough, Baylor Heart and Vascular Institute 621 N. Hall St., \#H030, Dallas, TX 75226, USA, Tel: (214) 820-7500 (O), (214) 820 7997; E-mail: Peter.McCullough@baylorhealth.edu

Received July 07, 2015; Accepted August 21, 2015; Published August 23, 2015

Citation: McCullough PA, Tumlin JA, Szerlip H, Vijayaraghavan K, Jyothinagaram S, et al. (2015) Cardiorenal Syndromes: Advances in Determining Diagnosis, Prognosis, and Therapy. J Cardiovasc Dis Diagn 3: 221. doi: 10.4172/23299517.1000221

Copyright: $\odot 2015$ McCullough PA, et al. This is an open-access article distributed under the terms of the Creative Commons Attribution License, which permits unrestricted use, distribution, and reproduction in any medium, provided the original author and source are credited. 
Citation: McCullough PA, Tumlin JA, Szerlip H, Vijayaraghavan K, Jyothinagaram S, et al. (2015) Cardiorenal Syndromes: Advances in Determining Diagnosis, Prognosis, and Therapy. J Cardiovasc Dis Diagn 3: 221. doi: 10.4172/2329-9517.1000221

Cardiorenal Syndrome (CRS) General Definition:

A pathophysiologic disorder of the heart and kidneys whereby acute or chronic dysfunction in one organ may induce acute or chronic dysfunction in the other organ

\section{CRS Type I (Acute Cardiorenal Syndrome)}

Abrupt worsening of cardiac function (i.e. acute heart failure) leading to acute kidney injury

- Major mechanisms: neurohormonal, abnormal cell signaling, hemodynamic derangements

-Opportunities: identify the $\sim 25 \%$ of HF that will develop AKI, test novel drugs/strategies

\section{CRS Type II (Chronic Cardiorenal Syndrome)}

Chronic abnormalities in cardiac function (i.e. chronic heart failure) leading to progressive and permanent chronic kidney disease

- Major mechanisms: chronic neurohormonal hyperactivation

- Opportunities: control risk of hyperkalemia and intensify ACEI or ARB, MRA, BB

\section{CRS Type III (Acute Renocardiac Syndrome)}

Abrupt worsening of renal function (i.e. AKI) leading to acute cardiac disorder (e.g. acute heart

failure, arrhythmia)

- Major mechanisms: acute volume overload, hyperkalemia, acidosis

- Opportunities: Novel drugs/strategies to prevent or treat AKI and improve cardiac outcomes/reduce complications

\section{CRS Type IV (Chronic Renocardiac Syndrome)}

Chronic kidney disease (e.g. chronic glomerular disease) contributing to decreased cardiac function, cardiac hypertrophy and/or increased risk of adverse cardiovascular events

- Major mechanisms: chronic pressure and volume overload, uremic cardiomyopathy, metabolic/micronutirent degrangment

- Opportunities: SGLT2 inhibitors, low dose ET-A antagonisits, control risk of hyperkalemia and intensify ACEI or ARB, MRA, treat metabolic abnormalities (uric acid, anemia, bone and mineral disorder, micronutrient abnormalities

CRS Type V (Secondary Cardiorenal Syndrome)

Systemic condition (e.g. sepsis) causing both cardiac and renal dysfunction

- Major mechanisms: cytokine storm danger associated molecular patterns

- Opportunities: acute cyokine reduction, immunomodulation, adavancd life suppport

Figure 1: Classification of five CRS.

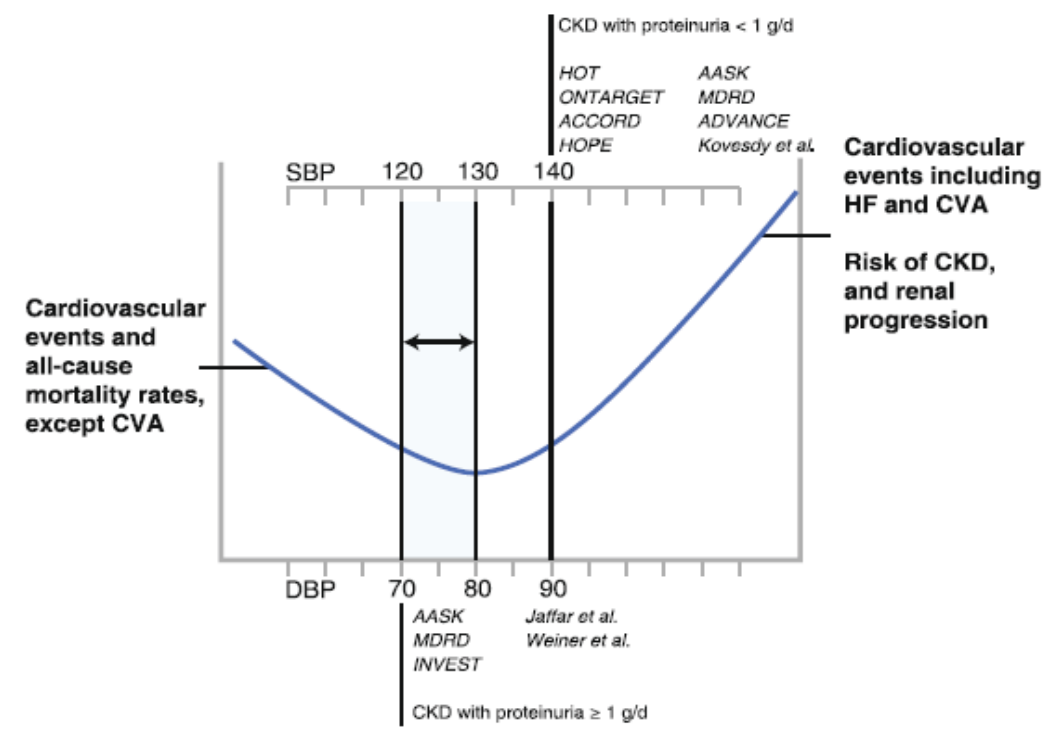

Figure 2: U-shaped relationship for treated blood pressure and cardiac and renal outcomes from clinical trials.

(chronic HF leading to progressive CKD) and Type 4 (CKD and its related hemodynamic and metabolic changes leading to myocardial dysfunction and HF). A notable feature of Type 4 CRS is accelerated myocardial and tubulointerstitial fibrosis. Fibrosis in the myocardium is directly related to mechanical dysfunction and arrhythmogenesis (atrial fibrillation and re-entrant ventricular tachycardia resulting in ventricular fibrillation). The most common conditions that lead to chronic CRS are hypertension and diabetes mellitus. While it is possible that diseases without either of these conditions can be present such as polycystic kidney disease, vesiculo-ureteral reflux, or IgA nephropathy, when we discuss chronic CRS we consider either diabetes or hypertension or both to be nearly universally present.

\section{Impact of Blood Pressure Control on the Heart and Kidneys}

For many years, systemic blood pressure has been a clinical target in both heart and kidney disease [7,8]. For the reduction in disease progression in both organs, blood pressure control is a cornerstone of management. The cardiovascular outcomes most responsive to 
blood pressure control are stroke and heart failure (Figure 2) [9]. Likewise, blood pressure control in $\mathrm{CKD}$ is associated with reductions in proteinuria, a slower decline in loss of eGFR, and reduced rates of incident ESRD. Thus a major current therapeutic target for management of chronic CRS is blood pressure with the caveat that for both organs there is a U-shaped relationship with outcomes as illustrated in the Figure 2 [9]. Given the dozens of available agents to treat hypertension, there is little development activity at this time for novel agents that would be of particular or unique benefit in CRS. The National Institutes of Health Systolic Blood Pressure Intervention Trial (SPRINT) will test in 9250 adults over age 50 a strategy of intensive blood pressure control versus standard control on the outcome of first occurrence of a myocardial infarction, acute coronary syndrome, and stroke, heart failure, or CVD death. In this study, there is a prespecified CKD subgroup would serve as an excellent validation for the event curve presented in Figure 2 [10].

\section{Treatment of Diabetes and Newer Antidiabetic Agents}

The control of blood glucose over time as reflected in the hemoglobin $\mathrm{A} 1 \mathrm{C}$ has been a mainstay of therapy to slow the progression of CKD (termed "microvascular disease" in trials) and reduce the incidence of binary events such as myocardial infarction or stroke. As a general observation, the impact of glycemic control has a larger benefit on the kidneys than the heart particularly with respect to atherosclerosis and heart failure. In fact, there are particular caveats for the cardiorenal system and treatment of diabetes that are twofold: 1) tight glycemic control that results in hypoglycemia may trigger myocardial infarction and cardiovascular death, 2) certain antidiabetic agents have direct adverse myocardial effects that can either mask ischemia or lead to the development of myocardial dysfunction, fluid overload, and heart failure (sulfonylureas, peroxisome proliferatoractivated receptor (PPAR) agonists, and possibly dipeptidyl peptidase 4 (DPP4) inhibitors) [11-13]. We recognize there is considerable controversy around the cardiovascular safety of antidiabetic drugs, but we make the point that if a safety risk exists, it is in patients with CKD for the outcome of heart failure which has been overlooked by regulatory guidance documents and in the design of many clinical trials which have focused on myocardial infarction, stroke, and cardiovascular death. Thus, unlike antihypertensive agents, there is considerable interest in novel anti diabetic agents that could overcome these limitations and more favorably affect patients with chronic CRS. The discovery and development of inhibitors of the sodium-glucose transporter-2 (SGLT) have generated considerable interest in the cardiorenal community. These agents inhibit the tubular reabsorption of sodium and glucose in the proximal tubule and thus enhance losses of both sodium and glucose resulting in lower blood pressure (without a concomitant heart rate increase), and reduced serum glucose and hemoglobin A1C. In addition to alpha-glucosidase inhibitors, SGLT inhibitors (canaglifozin, dapaglifozin, empagliflozin) work to limit the availability of glucose to cells and result in a net loss of glucose containing calories to the body [14]. This creates a scenario favorable to weight loss and improved cardiometabolic status; which along with osmotic dieresis and lower blood pressure may theoretically decrease the risk of developing HF (although this has yet to be formally tested). Clinical trials are underway to evaluate SGLT-2 inhibitors for major cardiac and renal events including myocardial infarction, stroke, cardiovascular death, progression of CKD, and ESRD) [15]. It should be noted that the efficacy of SGLT-2 inhibitors depends on renal filtration in order to clear glucose in the urine, and thus these agents would have declining efficacy in very low eGFR patients.

\section{Current Medical Therapy for Chronic Myocardial and Renal Disease}

In terms of medicinal therapy, several classes of agents have favorable effects on both the heart and the kidneys primarily in the setting of chronic management. It has been long-recognized that agents that antagonize the renin-angiotensin system in general have beneficial effects on both the heart and kidneys including reductions in left ventricular hypertrophy, reductions in heart failure hospitalization and death, and to a lesser extent reductions in myocardial infarction and stroke; and for the kidneys, lessening of proteinuria, and delayed progression of CKD to ESRD. In general, angiotensin-converting enzyme inhibitors (ACEI) have the most solid base of evidence for benefit in heart disease as well as kidney disease. For those who ACEIintolerant, angiotensin II receptor antagonists (ARB) have a clinical role. However, despite early enthusiasm with dual therapy, the use of ACEI and ARB together has resulted in an unfavorable risk/benefit balance with higher rates of acute kidney injury, hyperkalemia, and hypotension [16]. The additional use of direct renin-inhibitors has also not been shown to have added benefit over ACEI or ARB alone [17]. The chronic use of beta-adrenergic receptor antagonists and mineralocorticoid receptor antagonists (MRA) in general has been associated with improved cardiorenal outcomes provided they are tolerated and free of toxicities including hypotension and hyperkalemia [18]. It is reasonable to infer that the true potential impact of MRA use in patients with significant CKD has not been realized because of dose limiting or prohibiting effects of hyperkalemia [19]. Thus, as indicated below, novel agents to control potassium could indirectly allow a greater use of both RAAS-i and MRAs with potential positive impact on the outcomes of patients with CKD (particularly when combined with HF) in the community.

\section{Therapeutic Targets Beyond Blood Pressure and Glucose}

Considerable efforts have been undertaken to understand the range of metabolic perturbations that occur in CKD and evaluate their modification in terms of both renal and cardiac outcomes. Many of these factors (acidosis, iron, vitamin D, calcium, phosphorus, parathyroid hormone, fibroblast growth factors, erythropoietin, anemia, uric acid, oxidative stress, etc.) have their own set of confounders that can range from diet, lifestyle, socioeconomic status, to complex biologic interplays and medication effects [20]. Needless to say, it has been difficult to identify a single causative factor for incident or accelerated cardiovascular disease in CKD patients. Clinical trials have worked through many of these factors in search of fulfilling Koch's hypothesis, that is, change the putative factor and influence the outcome. To date, modifications of a factor such as hemoglobin, parathyroid hormone, or oxidative stress have resulted in no demonstrable benefit, direct toxicity, or off-target deleterious effects leading to cessation of clinical development. Importantly, most of these trials have broadly included patients with CKD with little profiling of populations or strategic use of therapies. Thus, important subgroups for benefit or harm may have been missed. In addition, there have been little or no attempts at mitigating risk for toxicities. For example, in clinical trials of erythrocyte simulating agents (erythropoietin, darbepoetin) there was no effort to exclude patients with resistance to these agents, and as a result patients were subjected to supraphysiologic doses of these agents which had cardiovascular toxicity (e.g. hypertension, stroke, heart failure) [21]. In the case of studies on anemia, the practicing community has been left with considerable confusion over the cause of the adverse outcome: was it secondary to raising hemoglobin or supraphysiologic dosing of the study drugs. Another notable development was the attempt to modify 
detoxification enzymes and reduce oxidative stress with bardoxolone, which improved eGFR but in a large clinical trial precipitated acutely decompensated heart failure and related mortality [22]. In this example, there were insufficient efforts to mitigate the potential risks of fluid overload [23]. As a result, many CKD trials exclude patients with a prior history of HF or elevations of BNP in order to mitigate against potential cardiotoxicity [24].

Despite these prior setbacks, the future remains bright in terms of exploration of treatments for CKD that would reduce the rate of progression and at the same time lessen the burden of cardiovascular disease. Among hopeful strategies are the use of novel oral and intravenous iron preparations, inhibitors of hypoxia-inducible factor prolyl hydroxylase prolyase, endothelin receptor antagonists, xanthine oxidase inhibitors, treatment of acidosis, designer natriuretic peptides and anti-fibrotic agents including partial inhibitors of galectin-3. Two particularly advanced areas of therapies include newer antidiabetic agents and potassium binders.

\section{Current in vitro Diagnostic Tests in Chronic Management of Cardiorenal Disease}

In terms of in vitro diagnostic tests, it has been appreciated that blood B-type natriuretic peptide (BNP) and NT-terminal proBNP (NT-proBNP) reflect a heart-kidney hormonal system that signals increased wall tension in the cardiac chambers with a message to the kidneys to increase natriuresis, diuresis, and lower blood pressure [25]. In asymptomatic patients with $\mathrm{CKD}$, elevations in $\mathrm{BNP}$ are strongly predictive for the future development of $\mathrm{HF}$, and thus are used clinically in risk stratification and in clinical trials of novel CKD treatments for risk mitigation for the development of $\mathrm{HF}$ as a serious adverse event [26]. There are now a host of acute and chronic disease markers in cardiorenal disease which are in either clinical use or development that will play a major role in the screening, detection, prognosis, and management of disease [27]. A list of selected chronic cardiorenal biomarkers is shown given in Table 1. Cardiac blood biomarkers in the chronic setting that reflect accelerated apoptosis and cell turnover include troponin I and T. With the use of super-sensitive assays for these proteins, most patients with CKD have detectable levels and the plasma concentration at steady state is related to increased risk of heart failure hospitalization and death in patients with CKD. Suppressor of tumorigenicity 2 (ST2) is a decoy protein produced by the endothelial lining of the left ventricle and aortic outflow tract that blocks the interleukin-33 (IL-33) receptor on cardiomyocytes and satellite cells and impairs the favorable IL-33 signal to these cells, and thus turns on cellular processes that promote myocyte dysfunction and fibrosis [28]. ST2 appears to be unaffected by reductions in eGFR, although there is evidence that with increase in renal fibrosis, there may be elevations in ST2 levels. Galectin-3 is an animal lectin which is secreted by macrophages in solid organs (heart, kidney, liver) and stimulates fibroblasts to proliferate and secrete procollagen I which is crosslinked to mature collagen fibers in the extracellular matrix. Galectin-3 has been found to be reflective of both cardiac and renal fibrosis and is the first directly pathogenic measurable blood factor in cardiorenal disease [2931]. All four of these markers (BNP/NT-proBNP, troponin I/T, ST2, and galectin-3) are recommended for use by the most recent American College of Cardiology/American Heart Association Guideline for the diagnosis and management of heart failure [32]

In terms of biomarker guidance in the management of $\mathrm{CKD}$, the reliance on serum creatinine and urine albumin or protein as markers of disease progression has been both a guiding principal but also a retardant for breakthrough treatments. A doubling of serum creatinine which is a common endpoint in CKD trials requires a 57\% reduction in eGFR [33]. Thus to witness an "important clinical signal" is to observe greater than half of organ function to be lost which cannot recover. This paradigm has led to stagnation in clinical development of agents to reduce the progression of CKD. A recent proposal that

\begin{tabular}{|c|c|c|c|c|c|c|c|c|}
\hline Biomarkers & Current Status & $\begin{array}{l}\text { Biological and } \\
\text { Physiological } \\
\text { Properties }\end{array}$ & $\begin{array}{l}\text { Measurable in } \\
\text { Plasma, Serum } \\
\text { or Blood }\end{array}$ & $\begin{array}{l}\text { Measurable in } \\
\text { Urine }\end{array}$ & $\begin{array}{l}\text { In Vitro } \\
\text { Diagnostic } \\
\text { Target }^{\S}\end{array}$ & $\begin{array}{l}\text { Potential Clinical } \\
\text { Utility and Guided } \\
\text { Therapeutic Targets }\end{array}$ & $\begin{array}{l}\text { Characteristic } \\
\text { Features }\end{array}$ & References \\
\hline \multicolumn{9}{|l|}{ Cardiac specific } \\
\hline $\begin{array}{l}\text { Cardiac troponin } \\
\mathrm{T}^{+}\end{array}$ & $\begin{array}{l}\text { An emerging } \\
\text { marker for } \\
\text { detecting CAD or } \\
\text { ACS in CKD pts. }\end{array}$ & $\begin{array}{l}\text { Troponins are } \\
\text { released from cardiac } \\
\text { muscle in proportion } \\
\text { to the degree of } \\
\text { muscle injury. }\end{array}$ & Plasma ELISA & No & No & $\begin{array}{l}\text { Pts with CKD and } \\
\text { suspected ACS }\end{array}$ & $\begin{array}{l}\text { In pts with AKD and } \\
\text { suspected ACS, } \\
\text { cTnT sensitivity } \\
(71 \% \text { to } 100 \%) \text { and } \\
\text { specificity }(31 \% \text { to } \\
86 \%) \text {, }\end{array}$ & [51-53] \\
\hline $\begin{array}{l}\text { Cardiac troponin } \\
\mathrm{I}^{+}\end{array}$ & $\begin{array}{l}\text { An emerging } \\
\text { marker for } \\
\text { detecting CAD or } \\
\text { ACS in CKD pts. }\end{array}$ & $\begin{array}{l}\text { Troponins are } \\
\text { released from cardiac } \\
\text { muscle in proportion } \\
\text { to the degree of } \\
\text { muscle injury. }\end{array}$ & Plasma ELISA & No & No & $\begin{array}{l}\text { Pts with CKD and } \\
\text { suspected ACS }\end{array}$ & $\begin{array}{l}\text { In pts with AKD and } \\
\text { suspected ACS, } \\
\text { cTnl sensitivity } \\
(43 \% \text { to } 94 \%) \text { and } \\
\text { specificity ( } 48 \% \text { to } \\
100 \%) .\end{array}$ & {$[52,53]$} \\
\hline $\begin{array}{l}\text { High-sensitivity } \\
\mathrm{TnT}^{\dagger}\end{array}$ & $\begin{array}{l}\text { An emerging high- } \\
\text { sensitivity troponin } \\
\text { marker in pts with } \\
\text { CKD }\end{array}$ & $\begin{array}{l}\text { Elevated hsTnT } \\
\text { in pts with CKD } \\
\text { due to previous } \\
\text { MI, unrecognized } \\
\text { ischemia, } \\
\text { cardiac stress, } \\
\text { ventricular fibrosis, } \\
\text { left ventricular } \\
\text { hypertrophy and } \\
\text { dilation, inflammation, } \\
\text { endothelial } \\
\text { dysfunction, and } \\
\text { other cardiac injury. }\end{array}$ & $\begin{array}{l}\text { Baseline } \leq 5.0 \\
\text { to } 378.7 \mathrm{pg} / \mathrm{ml}\end{array}$ & No & No & $\begin{array}{l}\text { Pts with mild to severe } \\
\text { CKD }\end{array}$ & $\begin{array}{l}\text { A sensitive and } \\
\text { specific marker } \\
\text { for incident HF } \\
\text { in pts with CKD } \\
\text { (the highest } \\
\text { quintile > } 26.5 \\
\text { ng/ml for HF vs. } \\
\text { undetectable hsTnT } \\
\text { for individuals) } \\
\text { (a 5-fold risk of } \\
\text { incident HF). } \\
\text { Note: higher hsTnT } \\
\text { levels in men vs } \\
\text { women and in } \\
\text { blacks vs. whites. }\end{array}$ & . \\
\hline
\end{tabular}


Citation: McCullough PA, Tumlin JA, Szerlip H, Vijayaraghavan K, Jyothinagaram S, et al. (2015) Cardiorenal Syndromes: Advances in Determining Diagnosis, Prognosis, and Therapy. J Cardiovasc Dis Diagn 3: 221. doi: 10.4172/2329-9517.1000221

\begin{tabular}{|c|c|c|c|c|c|c|c|c|}
\hline Galectin- $3^{\dagger}$ & $\begin{array}{l}\text { An emerging } \\
\text { myocardial } \\
\text { fibrosis marker for } \\
\text { prognosis of CHF. }\end{array}$ & $\begin{array}{l}\text { Gal-3 is a soluble } \\
\beta \text {-galactoside-binding } \\
\text { lectin that plays a } \\
\text { role in cardiac fibrosis } \\
\text { and remodeling in } \\
\text { CHF. }\end{array}$ & $\begin{array}{l}\text { Plasma, ELISA } \\
\text { (BG medicine, } \\
\text { Inc., USA). ) } \\
\text { (Cut-off value = } \\
17.7 \mathrm{ng} / \mathrm{mL})\end{array}$ & No & No & $\begin{array}{l}\text { Theraprutic potential } \\
\text { in pts with chronic HF. }\end{array}$ & $\begin{array}{l}\text { A good prognostic } \\
\text { marker for mortality } \\
\text { of pts with CHF } \\
\text { (AUC-ROC = } \\
0.612 \text { ) (Value } \\
\text { levels } 20.1 \pm 8.1 \\
\text { for the died vs. } \\
17.5 \pm 7.4 \mathrm{ng} / \mathrm{mL} \text { for } \\
\text { survivors). } \\
\text { A prognostic } \\
\text { marker for mortality } \\
\text { of pts with CHD. } \\
\text { MRAs treatment } \\
\text { does not affect } \\
\text { prognostic value of } \\
>17.8 \text { ng/mL. } \\
\text { A non-heart } \\
\text { target specific } \\
\text { (fibrosis of liver } \\
\text { and kidney also } \\
\text { involved). }\end{array}$ & {$[55,56]$} \\
\hline $\begin{array}{l}\text { B-type natriuretic } \\
\text { peptide }\end{array}$ & $\begin{array}{l}\text { An emerging } \\
\text { marker of } \\
\text { diagnosis, } \\
\text { prognosis, and } \\
\text { management of } \\
\text { HF pts and CKD } \\
\text { pts. }\end{array}$ & $\begin{array}{l}\text { A hormone produced } \\
\text { by ventricular } \\
\text { myocardium } \\
\text { in response to } \\
\text { ventricular stretching } \\
\text { and wall stress. }\end{array}$ & Plasma ELISA & No & No & $\begin{array}{l}\text { Identifying pts with } \\
\text { any degree of cardiac } \\
\text { dysfunction; Identifying } \\
\text { pts at increased risk } \\
\text { for sudden death; } \\
\text { Helping clinicians in } \\
\text { planning discharge of } \\
\text { HF pts; } \\
\text { Therapeutic targets: } \\
\text { HF in elderly pts, } \\
\text { significant different } \\
\text { from standard therapy. }\end{array}$ & $\begin{array}{l}\text { A high sensitivity } \\
\text { and accuracy: } \\
\text { Concentration } \\
\text { of }>100 \mathrm{pg} / \mathrm{mL} \\
\text { diagnosed HF with } \\
\text { a } 90 \% \text { sensitivity } \\
\text { and } 76 \% \text { specificity. } \\
\text { A useful marker } \\
\text { of cardiovascular } \\
\text { risk in CKD ptsand } \\
\text { progression of } \\
\text { decreased renal } \\
\text { function. }\end{array}$ & {$[52,55]$} \\
\hline $\begin{array}{l}\text { N-terminal pro } \\
\text { b-type natriuretic } \\
\text { peptide }\end{array}$ & $\begin{array}{l}\text { An emerging } \\
\text { marker of } \\
\text { diagnosis, } \\
\text { prognosis, and } \\
\text { management of } \\
\text { HF pts and CKD } \\
\text { pts. }\end{array}$ & $\begin{array}{l}\text { NT-proBNP is } \\
\text { secreted from } \\
\text { cardiomyocytes } \\
\text { in response to } \\
\text { myocardial stretch. } \\
\text { It reflects myocardial } \\
\text { stress induced } \\
\text { by volume or } \\
\text { pressure changes. } \\
\text { Its levels increase } \\
\text { with increasing left } \\
\text { ventricular mass. }\end{array}$ & $\begin{array}{l}\text { Baseline } \leq 5 \text { to } \\
35,000 \mathrm{pg} / \mathrm{ml} \text {. }\end{array}$ & & & $\begin{array}{l}\text { Therapeutic targets, } \\
\text { Pts with mild to severe } \\
\text { CKD }\end{array}$ & $\begin{array}{l}\text { A sensitive, } \\
\text { specific and } \\
\text { predictive marker } \\
\text { for incident HF in } \\
\text { pts with CKD (the } \\
\text { highest quintile }> \\
433.05 \mathrm{ng} / \mathrm{ml} \text { for HF } \\
\text { vs. }<47.6 \mathrm{ng} / \mathrm{ml} \text { for } \\
\text { lowest quintile of } \\
\text { individuals)(a } 10- \\
\text { fold higher rate of } \\
\text { incident HF). } \\
\text { A useful marker of } \\
\text { cardiovascular risk } \\
\text { in CKD pts. } \\
\text { A predictor of } \\
\text { mortality in CKD } \\
\text { pts. } \\
\text { AUC-ROC }=0.795 \\
\text { NT-proBNP, } \\
\text { A prognostic } \\
\text { marker of } \\
\text { predicting CHF } \\
\text { and acute coronary } \\
\text { symptom. } \\
\text { Note: Half-life of } \\
\text { proBNP is longer } \\
\text { and its levels are } \\
\text { more stable than } \\
\text { BNP and less } \\
\text { affected by acute } \\
\text { stress. }\end{array}$ & {$[52,55,57]$} \\
\hline $\begin{array}{l}\text { Creatine kinsase } \\
\text { myocardial band }\end{array}$ & $\begin{array}{l}\text { An emerging } \\
\text { cardiac marker for } \\
\text { predictive AKI }\end{array}$ & $\begin{array}{l}\text { CK-MB released } \\
\text { from damaged } \\
\text { myocardium. Higher } \\
\text { levels reduce } \\
\text { cardiac reserve at } \\
\text { baseline and result } \\
\text { in hemodynamic } \\
\text { instability, whereby } \\
\text { they lead to greater } \\
\text { risk of postsurgical } \\
\text { AKI. }\end{array}$ & $\begin{array}{l}\text { Beckman } \\
\text { Coulter Access } \\
\text { II instrument for } \\
\text { CK-MB. }\end{array}$ & No & No & $\begin{array}{l}\text { Prediction of } \\
\text { postoperative } \mathrm{AKI} \text { in } \\
\text { children with cardiac } \\
\text { surgery. }\end{array}$ & $\begin{array}{l}\text { A good predictive } \\
\text { marker (AUC-ROC } \\
\text { for CK-MB = 0.77). }\end{array}$ & [58] \\
\hline
\end{tabular}


Citation: McCullough PA, Tumlin JA, Szerlip H, Vijayaraghavan K, Jyothinagaram S, et al. (2015) Cardiorenal Syndromes: Advances in Determining Diagnosis, Prognosis, and Therapy. J Cardiovasc Dis Diagn 3: 221. doi: 10.4172/2329-9517.1000221

\begin{tabular}{|c|c|c|c|c|c|c|c|c|}
\hline $\begin{array}{l}\text { Heart-type fatty } \\
\text { acid binding } \\
\text { protein }\end{array}$ & $\begin{array}{l}\text { An emerging } \\
\text { cardiac marker for } \\
\text { predictive AKI }\end{array}$ & $\begin{array}{l}\text { h-FABP released } \\
\text { from damaged } \\
\text { myocardium. Higher } \\
\text { levels reduce } \\
\text { cardiac reserve at } \\
\text { baseline and result } \\
\text { in hemodynamic } \\
\text { instability, whereby } \\
\text { they lead to greater } \\
\text { risk of postsurgical } \\
\text { AKI. }\end{array}$ & $\begin{array}{l}\text { Evidence } \\
\text { Investigator } \\
\text { Cytokine } \\
\text { Custom Array } \\
\text { for h-FABP }\end{array}$ & No & No & $\begin{array}{l}\text { Prediction of } \\
\text { postoperative AKI in } \\
\text { children with cardiac } \\
\text { surgery. }\end{array}$ & $\begin{array}{l}\text { A good predictive } \\
\text { marker }(A U C-R O C \\
\text { for } h-F A B P=0.78)\end{array}$ & [58] \\
\hline $\begin{array}{l}\text { Supressor of } \\
\text { tumorigenicity-2 }\end{array}$ & $\begin{array}{l}\text { A emerging } \\
\text { marker of } \\
\text { cardiomyocyte } \\
\text { stress, cardiac } \\
\text { remodeling and } \\
\text { fibrosis }\end{array}$ & $\begin{array}{l}\text { ST2 is an IL-1 } \\
\text { receptor family } \\
\text { member expressed } \\
\text { in cardiac myocytes, } \\
\text { fibroblasts and } \\
\text { endothelium. } \\
\text { In response to } \\
\text { inflammation and } \\
\text { cardiac stress, IL33/ } \\
\text { ST2 signaling is } \\
\text { activated and soluble } \\
\text { ST2 is released into } \\
\text { blood. ST2 acts as } \\
\text { cardioprotective } \\
\text { signaling pathway } \\
\text { resulting in reduced } \\
\text { hypertrophy and } \\
\text { myocardial fibrosis. }\end{array}$ & $\begin{array}{l}\text { ELISA (RandD } \\
\text { Systems } \\
\text { Europe, Ltd., } \\
\text { UK). }\end{array}$ & No & No & $\begin{array}{l}\text { Potential value of } \\
\text { ST2 for guidance of } \\
\text { therapy with ACEi, } \\
\text { ARBs, MRAs, and } \\
\beta \text {-blockers. }\end{array}$ & $\begin{array}{l}\text { A predictive of } \\
\text { cardiovascular } \\
\text { admission or } \\
\text { WRF in pts with } \\
\text { pharmacologically } \\
\text { optimised CHF; } \\
\text { A good biomarker } \\
\text { (AUC-ROC } \\
=0.778 \text { ). } \\
\text { A cardiovascular } \\
\text { prognostic marker } \\
\text { in CHF. } \\
\text { It service as a } \\
\text { guideline-endorsed } \\
\text { biomarker } \\
\text { of cardiovascular } \\
\text { risk. }\end{array}$ & {$[55,59-62]$} \\
\hline $\begin{array}{l}\text { Glutamic acid } \\
\text { decarboxylase } \\
15\end{array}$ & $\begin{array}{l}\text { A emerging } \\
\text { markers of } \mathrm{CHF} \\
\text { with CAD }\end{array}$ & $\begin{array}{l}\text { A stress protein of } \\
\text { transforming growth } \\
\text { factor- } \beta \text { superfamily } \\
\text { (also known as } \\
\text { macrophage inhibitor } \\
\text { cytokine-1). It } \\
\text { has protective } \\
\text { effect on coronary } \\
\text { artery. It involves in } \\
\text { myocardial injury and } \\
\text { fibrosis. }\end{array}$ & $\begin{array}{l}\text { Plasma } \\
\text { (ELISA): USCN } \\
\text { Life Science, } \\
\text { Inc. China). }\end{array}$ & No & No & CHF pts. & $\begin{array}{l}\text { A diagnostic } \\
\text { markers of CHF } \\
\text { with CAD; } \\
\text { A good biomarker"l } \\
\text { (AUC-ROC = } \\
\text { 0.804). } \\
\text { A prognostic } \\
\text { marker of } \\
\text { predicting CHF } \\
\text { and acute coronary } \\
\text { symptom. }\end{array}$ & {$[57]$} \\
\hline \multicolumn{9}{|c|}{ Cardiorenal specific } \\
\hline $\begin{array}{l}\text { a-2 } \\
\text { microglobulin }\end{array}$ & $\begin{array}{l}\text { An emerging novel } \\
\text { marker of PMI and } \\
\text { diabetes. }\end{array}$ & $\begin{array}{l}\alpha 2 \mathrm{M} \text { is synthesized } \\
\text { in liver and locally by } \\
\text { macrophage. } \alpha 2 \mathrm{M} \\
\text { acts as a transporter } \\
\text { for cytokines/ } \\
\text { growth factor and } \\
\text { an endogenous } \\
\text { inhibitor of circulating } \\
\text { proteases. Human } \\
\text { cardiac isoform of } \\
\alpha 2 \mathrm{M} \text { is identical } \\
\text { to human serum } \\
\text { monomeric } \alpha 2 \mathrm{M} \text {. }\end{array}$ & $\begin{array}{l}\text { Serum or } \\
\text { plasma (ELISA) }\end{array}$ & No & $\begin{array}{l}\text { Proteomic } \\
\text { analysis } \\
\text { of serum } \\
\text { example. }\end{array}$ & Diabetic pts & $\begin{array}{l}\text { Cardiac isoform of } \\
\text { a2M: A diagnostic } \\
\text { marker of diabetic } \\
\text { pts with PMl or } \\
\text { cardiac disease; } \\
\text { Serum monomeric } \\
\text { a2M: A diagnostic } \\
\text { marker of diabetic } \\
\text { nephropathy } \\
\text { (positive } \\
\text { correlations } \\
\text { between a2M with } \\
\text { urinary albumin and } \\
\text { HbA1c.) }\end{array}$ & {$[63,64]$} \\
\hline $\begin{array}{l}\text { Asymmetric } \\
\text { dimethyl arginine }\end{array}$ & $\begin{array}{l}\text { An emerging } \\
\text { marker of CKD } \\
\text { and cardiovascular } \\
\text { event. }\end{array}$ & $\begin{array}{l}\text { An endogenous } \\
\text { inhibitor of NOS. } \\
\text { ADMA has profound } \\
\text { renal hemodynamic } \\
\text { effects. }\end{array}$ & Plasma & No & No & No & $\begin{array}{l}\text { A strong predictor } \\
\text { of renal disease } \\
\text { progression in pts } \\
\text { with CKD. } \\
\text { ADMA is } \\
\text { associated with } \\
\text { progression of } \\
\text { carotid intima } \\
\text { media thickness, } \\
\text { cardiac remoering, } \\
\text { and left ventricular } \\
\text { hypertrophy. }\end{array}$ & {$[52,65]$} \\
\hline \multicolumn{9}{|l|}{ Renal specific } \\
\hline Glom & & & & & & & & \\
\hline
\end{tabular}


Citation: McCullough PA, Tumlin JA, Szerlip H, Vijayaraghavan K, Jyothinagaram S, et al. (2015) Cardiorenal Syndromes: Advances in Determining Diagnosis, Prognosis, and Therapy. J Cardiovasc Dis Diagn 3: 221. doi: 10.4172/2329-9517.1000221

Page 7 of 28

\begin{tabular}{|c|c|c|c|c|c|c|c|c|}
\hline Albumin $^{\dagger}$ & $\begin{array}{l}\text { An emerging } \\
\text { marker of } \\
\text { monitoring } \\
\text { progression of } \\
\text { CKD. }\end{array}$ & $\begin{array}{l}\text { Low concentration } \\
\text { of protein in urine } \\
\text { in terms of its large } \\
\text { size and selectivity of } \\
\text { glomerular filtration } \\
\text { barrier and tubular } \\
\text { reabsorption. }\end{array}$ & No & $\begin{array}{l}\text { Normoalbuminuria, } \\
\text { microalbuminuria, } \\
\text { macroalbuminute } \\
\text { (UACR <30mg/g, } \\
30 \text { to } 299 \mathrm{mg} / \mathrm{g}, \\
>300 \mathrm{mg} / \mathrm{g} \text {, } \\
\text { respectively). }\end{array}$ & No & No & $\begin{array}{l}\text { A prognostic } \\
\text { marker for } \\
\text { monitoring reduced } \\
\text { GER, progression } \\
\text { of CKD, mortality } \\
\text { risk. }\end{array}$ & {$[66]$} \\
\hline Cystatin-C ${ }^{\dagger}$ & $\begin{array}{l}\text { An emerging } \\
\text { marker of kidney } \\
\text { filtration capacity. }\end{array}$ & $\begin{array}{l}\text { A protein of cysterine } \\
\text { proteinase inhibitory } \\
\text { family, which passes } \\
\text { glomerular basement } \\
\text { membrane and then } \\
\text { it is reabsorbed. }\end{array}$ & Serum & No & No & Pts with CHF. & $\begin{array}{l}\text { A prognostic } \\
\text { marker for more } \\
\text { accurate estimating } \\
\text { GFR and reflecting } \\
\text { a mild or moderate } \\
\text { decrease in renal } \\
\text { function in pts with } \\
\text { CHF; } \\
\text { No age, gender, } \\
\text { food, and body } \\
\text { mass affected. }\end{array}$ & {$[66]$} \\
\hline Podocin & $\begin{array}{l}\text { An emerging } \\
\text { marker of } \\
\text { glomerular } \\
\text { disease. }\end{array}$ & $\begin{array}{l}\text { Podocin (NPHS2) } \\
\text { is a component } \\
\text { of glomerular slit- } \\
\text { diaphragm, with } \\
\text { major regulatory } \\
\text { functions in renal } \\
\text { permeability of } \\
\text { proteins. Podocinloss } \\
\text { of podocin may } \\
\text { influence the } \\
\text { outcome of } \\
\text { proteinuric renal } \\
\text { disease. }\end{array}$ & No & Urine (ELISA) & $\begin{array}{l}\text { Urine } \\
\text { podocin/ } \\
\text { nephrin } \\
\text { ratio } \\
\text { mRNA as } \\
\text { a podocyte } \\
\text { stress } \\
\text { biomarker. }\end{array}$ & $\begin{array}{l}\text { A new therapeutic } \\
\text { insight for CKD. }\end{array}$ & $\begin{array}{l}\text { A predictor of } \\
\text { progression of } \\
\text { CKD (In pts with } \\
\text { lupus nephritis, } \\
\text { podocyturia with } \\
\text { anti-podocin } \\
\text { correlated as well } \\
\text { as urinary protein/ } \\
\text { creatinine ratio } \\
\text { showed significant } \\
\text { correlation with } \\
\text { degree of lupus } \\
\text { disease activity). }\end{array}$ & {$[67,68]$} \\
\hline Nephrin & $\begin{array}{l}\text { An emerging } \\
\text { marker of } \\
\text { glomerular } \\
\text { diseases. }\end{array}$ & $\begin{array}{l}\text { A transmembrane } \\
\text { protein that is } \\
\text { specifically located at } \\
\text { the slit diagphragm } \\
\text { of glomerular } \\
\text { podocytes. It } \\
\text { functions as a renal } \\
\text { filtration barrier and } \\
\text { regulates excretion. }\end{array}$ & No & Urine (ELISA) & $\begin{array}{l}\text { A defect in } \\
\text { gene for } \\
\text { nephrin, } \\
\text { NPHS1 } \\
\text { recognized. }\end{array}$ & NO & $\begin{array}{l}\text { The number of } \\
\text { podocytes and } \\
\text { levels of nephrin } \\
\text { in urine were } \\
\text { significantly higher } \\
\text { in lupus nephritis, } \\
\text { focal segmental } \\
\text { glomeronephritis, } \\
\text { and pts with severe } \\
\text { proteinuria. } \\
\text { A positive } \\
\text { correlation between } \\
\text { urinary nephrin } \\
\text { expression and } \\
\text { UACR. }\end{array}$ & [69] \\
\hline \multicolumn{9}{|c|}{ Proximal tubular-specific } \\
\hline $\begin{array}{l}\text { Kidney injury } \\
\text { molecule-1 } 1^{\prime ¥}\end{array}$ & $\begin{array}{l}\text { An emerging } \\
\text { marker of renal } \\
\text { dysfunction and } \\
\text { worse outcome in } \\
\text { CHF. }\end{array}$ & $\begin{array}{l}\text { A transmembrane } \\
\text { glycoprotein } \\
\text { expressed in } \\
\text { proximal tubular cell. } \\
\text { Injury to these tubular } \\
\text { cells leads to urinary } \\
\text { level increase. }\end{array}$ & Yes & Yes & No & No & $\begin{array}{l}\text { A prognostic } \\
\text { marker for more } \\
\text { accurate estimating } \\
\text { GFR and WRS in } \\
\text { pts with CHF. }\end{array}$ & {$[66]$} \\
\hline $\begin{array}{l}\text { Kidney injury } \\
\text { molecule-1 } 1^{1 ¥}\end{array}$ & $\begin{array}{l}\text { An emerging blood } \\
\text { biomarker for CKD } \\
\text { pts. }\end{array}$ & $\begin{array}{l}\text { Release of KIM-1 } \\
\text { into the blood is due } \\
\text { to loss of polarity } \\
\text { of injured tubular } \\
\text { cells, increased } \\
\text { transepithelial } \\
\text { permeability, and } \\
\text { altered microvasculr } \\
\text { permeability. }\end{array}$ & Serum & Urine & No & CKD pts. & $\begin{array}{l}\text { A specific and } \\
\text { sensitive marker } \\
\text { for CKD of various } \\
\text { etiologies; } \\
\text { A predictor of } \\
\text { progressive renal } \\
\text { decline: } \\
\text { In a cohort of pts } \\
\text { with type I diabetes } \\
\text { and proteinuria, } \\
\text { serum KIM-1 levels } \\
\text { at baseline strongly } \\
\text { predicted rate of } \\
\text { eGFR loss. and risk } \\
\text { of ESRD during } \\
5-15 \text { yrs of follow- } \\
\text { up, after adjustment } \\
\text { for baseline } \\
\text { urinary albumin- } \\
\text { to-creatinine ratio, } \\
\text { eGFR, and Hb1Ac. }\end{array}$ & [70] \\
\hline
\end{tabular}


Citation: McCullough PA, Tumlin JA, Szerlip H, Vijayaraghavan K, Jyothinagaram S, et al. (2015) Cardiorenal Syndromes: Advances in Determining Diagnosis, Prognosis, and Therapy. J Cardiovasc Dis Diagn 3: 221. doi: 10.4172/2329-9517.1000221

\begin{tabular}{|c|c|c|c|c|c|c|c|c|}
\hline Trefoil factor $3^{\dagger}$ & $\begin{array}{l}\text { An emerging } \\
\text { marker for kidney } \\
\text { injury in CKD pts. }\end{array}$ & $\begin{array}{l}\text { TFF3, a small } \\
\text { peptide, is expressed } \\
\text { in tubular epithelial } \\
\text { cells. Injury to } \\
\text { tubular cells leads } \\
\text { to increase of } \\
\text { TFF3 in sera and } \\
\text { urine. However, } \\
\text { glomerular injury } \\
\text { is not associated } \\
\text { with urinary TFF3 } \\
\text { excretion. TFF3 } \\
\text { may play roles in } \\
\text { regeneration and } \\
\text { restitution, and in } \\
\text { kidney damage } \\
\text { repair, as well as in } \\
\text { EMT process. }\end{array}$ & Serum (ELISA) & Urine (ELISA) & $\begin{array}{l}\text { TFF3 } \\
\text { mRNA } \\
\text { may be } \\
\text { candidate } \\
\text { marker. }\end{array}$ & CHD pts. & $\begin{array}{l}\text { A predictor for } \\
\text { progression of } \\
\text { kidney injury } \\
\text { for stages } 1-5 \\
\text { (Correlation of } \\
\text { serum TFF3 levels } \\
\text { with CKD stage: } \\
23.6 \mathrm{ng} / \mathrm{ml}, 29.9 \mathrm{ng} / \\
\mathrm{ml}, 54.9 \mathrm{ng} / \mathrm{ml}, \\
85.0 \mathrm{ng} / \mathrm{ml}, 176.6 \\
\mathrm{ng} / \mathrm{ml} \text { for stages } \\
1-5, \text { respectively } \\
\text { vs. normal control } \\
17.8 \mathrm{ng} / \mathrm{ml} \text { ). }\end{array}$ & [71] \\
\hline $\begin{array}{l}\text { Neutrophil } \\
\text { gelatinase } \\
\text { associated } \\
\text { lipocalin }\end{array}$ & $\begin{array}{l}\text { An emerging } \\
\text { marker of renal } \\
\text { dysfunction in } \\
\text { CHF. }\end{array}$ & $\begin{array}{l}\text { A lipocalin protein } \\
\text { produced by } \\
\text { kidney. Injury to } \\
\text { proximal tubule } \\
\text { leads to urinary level } \\
\text { increase. NGAL } \\
\text { mRNA is transcribed } \\
\text { and overexpressed } \\
\text { in loop of Henle } \\
\text { and collecting duct, } \\
\text { and thus urinary } \\
\text { levels increases } \\
\text { significantly. }\end{array}$ & Yes & Urine & & & $\begin{array}{l}\text { A prognostic } \\
\text { marker for more } \\
\text { accurate estimating } \\
\text { GFR and WRS in } \\
\text { CHF pts. } \\
\text { A weak marker } \\
\text { of risk for renal } \\
\text { function decline, } \\
\text { but might be a } \\
\text { predictor of cardiac } \\
\text { event in HF pts with } \\
\text { and without renal } \\
\text { disease. }\end{array}$ & {$[52,66]$} \\
\hline $\begin{array}{l}\mathrm{N} \text {-acetyl- } \beta-\mathrm{D}- \\
\text { glucosaminidase }\end{array}$ & $\begin{array}{l}\text { An emerging } \\
\text { marker of renal } \\
\text { dysfunction and } \\
\text { worse outcome in } \\
\text { CHF. }\end{array}$ & $\begin{array}{l}\text { A protein produced } \\
\text { in proximal tubular } \\
\text { cells, tubular injury } \\
\text { leads to its excretion } \\
\text { into urine. }\end{array}$ & No & Urine & No & No & $\begin{array}{l}\text { A prognostic } \\
\text { marker for more } \\
\text { accurate estimating } \\
\text { GFR and WRS in } \\
\text { pts with CHF. }\end{array}$ & [66] \\
\hline Interleukin-18 & $\begin{array}{l}\text { An emerging } \\
\text { marker of tubular } \\
\text { injury CHF. }\end{array}$ & $\begin{array}{l}\text { A cytokine secreted } \\
\text { by proximal tubular } \\
\text { cells. }\end{array}$ & No & Yes & No & No & $\begin{array}{l}\text { A prognostic } \\
\text { marker for WRS in } \\
\text { pts with CHF. } \\
\text { Not high specific; }\end{array}$ & {$[66]$} \\
\hline $\begin{array}{l}\text { L-type fatty acid } \\
\text { binding protein }\end{array}$ & $\begin{array}{l}\text { An emerging } \\
\text { marker of tubular } \\
\text { injury CHF. }\end{array}$ & $\begin{array}{l}\text { A protein binding free } \\
\text { fatty acids. Tubular } \\
\text { injury leads to } \\
\text { excretion of L-FABP. }\end{array}$ & No & Yes & No & No & $\begin{array}{l}\text { A prognostic } \\
\text { marker for worse } \\
\text { outcome in CHF. }\end{array}$ & [66] \\
\hline $\begin{array}{l}\text { Vascular } \\
\text { endothelial cell } \\
\text { growth factor }\end{array}$ & $\begin{array}{l}\text { An emerging } \\
\text { marker of CKD }\end{array}$ & $\begin{array}{l}\text { An endothelial cell- } \\
\text { specific mitogen. } \\
\text { The effects of VEGF } \\
\text { on endothelial cells } \\
\text { includes cell motility } \\
\text { and proliferation, } \\
\text { upregulation of } \\
\text { NOS, production } \\
\text { of prostaglandins, } \\
\text { modulation } \\
\text { of apoptosis, } \\
\text { permeability, } \\
\text { protection } \\
\text { mechanisms to } \\
\text { manage increased } \\
\text { shear stress, and } \\
\text { leukocyte adhesion. }\end{array}$ & Plasma & No & No & Diabetic CKD pts. & $\begin{array}{l}\text { A predictor of } \\
\text { progression of } \\
\text { ESRD. }\end{array}$ & [72] \\
\hline Osteopontin & $\begin{array}{l}\text { An emerging } \\
\text { marker of } \\
\text { incident diabetic } \\
\text { nephropathy }\end{array}$ & $\begin{array}{l}\text { A multifunctional } \\
\text { protein that is } \\
\text { biosynthesized by } \\
\text { a variety of tissues } \\
\text { including kidney. } \\
\text { OPN is expressed } \\
\text { in immune cells } \\
\text { (neutrophils, T and } \\
\text { B cells, and has } \\
\text { chemotactic property. }\end{array}$ & Serum (ELISA) & No & No & $\begin{array}{l}\text { Pts with type } 1 \\
\text { diabetes. }\end{array}$ & $\begin{array}{l}\text { A strong } \\
\text { predictor of } \\
\text { incident diabetic } \\
\text { nephropathy, } \\
\text { CVD, and all- } \\
\text { cause mortality } \\
\text { in pts with T, } \\
\text { (serum OPN } \\
\text { was higher in } \\
\text { pts developed } \\
\text { microalbumin, } \\
\text { progressed to } \\
\text { ESRD, incident } \\
\text { CVD, or died). }\end{array}$ & [73] \\
\hline
\end{tabular}


Citation: McCullough PA, Tumlin JA, Szerlip H, Vijayaraghavan K, Jyothinagaram S, et al. (2015) Cardiorenal Syndromes: Advances in Determining Diagnosis, Prognosis, and Therapy. J Cardiovasc Dis Diagn 3: 221. doi: 10.4172/2329-9517.1000221

\begin{tabular}{|c|c|c|c|c|c|c|c|c|}
\hline Megalin & $\begin{array}{l}\text { An emerging } \\
\text { marker of } \\
\text { dysfunction of } \\
\text { proximal tubular } \\
\text { reabsorption. }\end{array}$ & $\begin{array}{l}\text { A large multi-ligand } \\
\text { endocytic receptor } \\
\text { that play a role } \\
\text { in reabsorption } \\
\text { of filtered plasma } \\
\text { proteins, hormone } \\
\text { and vitamins by } \\
\text { proximal tubules. }\end{array}$ & No & Urine & $\begin{array}{l}\text { Megalin- } \\
\text { encoding } \\
\text { gene } \\
(L P R 2)\end{array}$ & $\begin{array}{l}\text { Pts with DB/FOAR } \\
\text { syndrome }\end{array}$ & $\begin{array}{l}\text { A diagnostic marker } \\
\text { for DB/FOAR due } \\
\text { to proximal tubular } \\
\text { dysfunction of } \\
\text { megalin. }\end{array}$ & [74] \\
\hline \multicolumn{9}{|c|}{ Unknown site-specific } \\
\hline Uromodulin & $\begin{array}{l}\text { An emerging } \\
\text { marker of CKD. }\end{array}$ & $\begin{array}{l}\text { Uromodulin (Tamm- } \\
\text { Horsfall protein) is } \\
\text { the most abundant } \\
\text { urinary protein in } \\
\text { healthy individuals } \\
\text { and play a role in } \\
\text { progress of IgA } \\
\text { nephropathy. }\end{array}$ & No & Urine (ELISA) & No & No & $\begin{array}{l}\text { A predictor of } \\
\text { IgA nephropathy } \\
\text { (Low urinary } \\
\text { uromodulin levels } \\
\text { were associated } \\
\text { with a faster } \\
\text { eGFR decline, } \\
\text { interstitial fibrosis/ } \\
\text { tubular atrophy, } \\
\text { and gender (higher } \\
\text { in female than in } \\
\text { man). }\end{array}$ & [75] \\
\hline $\begin{array}{l}\text { Wilm's tumor-1 } \\
\text { protein }\end{array}$ & $\begin{array}{l}\text { An emerging } \\
\text { marker of CKD. }\end{array}$ & $\begin{array}{l}\text { A transcription } \\
\text { factor in urinary } \\
\text { exosomes. The } \\
\text { sequence of events } \\
\text { leading to formation } \\
\text { of exosomes is } \\
\text { initiated by fusing } \\
\text { of endocytic vesicle } \\
\text { with multivesisicular } \\
\text { bodies MVB), } \\
\text { forming internal } \\
\text { vesicles within MVB } \\
\text { due to invaginated } \\
\text { membrane, fusing } \\
\text { of MVB with plasma } \\
\text { membrane, and then } \\
\text { internal vesicles } \\
\text { entering extracellular } \\
\text { space as exosomes. } \\
\text { It is suggested that a } \\
\text { rich source of kidney } \\
\text { injury biomarkers } \\
\text { are present in } \\
\text { urinary exosomes } \\
\text { because they contain } \\
\text { intracellular proteins. }\end{array}$ & No & $\begin{array}{l}\text { Urine (Western } \\
\text { blot). }\end{array}$ & No & Pts with CKD. & $\begin{array}{l}\text { A useful marker } \\
\text { of early podocyte } \\
\text { injury in ESRD pts. }\end{array}$ & [76] \\
\hline
\end{tabular}

*For biomarkers from preclinical biomarkers translated into clinical setting, several processes are needed, including bridging preclinical biomarkers to clinical biomarkers, validation of the biomarker, transplantation application of preclinical biomarkers into clinical setting, and clinical qualification. The table includes FDA approved 10 biomarker qualification (cTnl, cTnT, Alb, B2M, Clu, CysC, TUP, TFF3, Kim-1, RPA-1) for nonclinical use. The FDA approved biomarkers are also accepted for clinical observation under certain circumstances. Qualification is a conclusion that these biomarkers are sensitive and specific biomarkers for myocardial or kidney damage. FDA also approved 3 biomarkers (Gal3, TIMP-2/IGFBP7) for clinical setting, by using Galectin-3 Assay ${ }^{\top M}$ (BG Medicine) and NephroCheck ${ }^{\circledR}$ test (Astute Medical Inc., USA).

$\S$ FDA regulates in vitro diagnostic devices (IVD), and the biomarkers used in IVD typically include genomic, proteomic, and metabolomic biomarkers. ${ }^{\dagger}$ Cardiac troponins were reviewed by FDA as qualified biomarkers for nonclinical use on February 23, 2012. Qualification is a conclusion that cTnI and cTnT are sensitive and specific biomarkers for myocardial damage.

† 7 biomarkers were selected from 23 markers for kidney toxicity by FDA and EMA as qualified biomarkers for nonclinical use. Qualification is a conclusion that these biomarkers are sensitive and specific biomarkers for kidney damage.

¥FDA and EMA qualified KIM-1 as a urinary biomarker in clinical studies on case-by case basis.

Biomarker abbreviations

$\alpha 2 \mathrm{M}=\alpha-2$ macroglobulin; $\mathrm{ADMA}=$ asymmetric dimethylarginine; $\mathrm{Alb}=$ albumin; $\mathrm{BNP}=\mathrm{B}$-type natriuretic peptide; CK-MB = creatine kinase-MB; $\mathrm{cTnI}=$ cardiac troponin I; $\mathrm{cTnT}=$ cardiac troponin $\mathrm{T} ; \mathrm{CysC}=$ cystatin $\mathrm{C} ;$ hsTnT = high sensitivity troponn T; Gal3= galectin 3; GDF15 = growth differentiation factor 15 ; L-FABP = the liver type fatty acid binding protein; h-FABP = heart-type fatty acid binding protein; IL-18 = interleukin 18; Kim-1/KIM-1 = kidney injury molecule-1; NAG = N-acetyl- $\beta$-D-gl ucosaminidase $\mathrm{NGAL}=$ neutrophil gelatinase-associated lipocalin; NT-proBNP = N-terminal-pro-B type natriuretic peptide; OPN = osteopontin; ST2 = suppression of tumorigenity $2 ; \mathrm{TFF} 3$ $=$ trefoil factor 3; VEGE = vascular endothelial growth factor; WT-1= Wilms tumor 1.

Other abbreviations

$\mathrm{ACS}=$ acute coronary syndrome; $\mathrm{ADHF}=$ acute decompensated heart failure; $\mathrm{AH}=$ athlete's heart; $\mathrm{AHF}=$ acute heart failure; $\mathrm{AKI}=$ acute kidney injury; $\mathrm{ATL}=\mathrm{controls}$ $\mathrm{ATN}=$ acute tubular necrosis; $\mathrm{AUC}=$ area under a ROC curve; $\mathrm{CAD}=$ coronary artery disease; $\mathrm{CHF}=$ chronic heart failure; $\mathrm{CKD}=$ chronic kidney disease; $\mathrm{CVD}=$ cardiovascular disease; DB/FOAR = Donnai-Barrow/Facio-Oculo-Acustico-Renal; ELISA = enzyme-linked immunosorbent assay; EMA = European Medicines Agency; $\mathrm{EMT}$ = epithelial-to-mesenchymal transition; ESRD = end-stage renal disease; GFR = glomerular filtration rate; HF = heart failure; CRS = cardiorenal syndrome; MRAs = mineralocorticoid receptor antagonists; NO = nitric oxide; NOS= nitric oxide synthase; PMI = post myocardial infarction; pts = Patients; RAS = rennin-angiotensin system; $\mathrm{ROC}=$ receiver-operating characteristic; $\mathrm{T}, \mathrm{D}=$ type 1 diabetes; $\mathrm{UACR}=$ urine albumin/creatinine ratio; $\mathrm{WRF}=$ worsening renal function; $\mathrm{yr}=$ year

Table 1: Clinical biomarkers* used or proposed for type 2 chronic cardiorenal syndrome or type 4 chronic renocardiac syndrome. 
a $30 \%$ or $40 \%$ loss of function over one to two years would be a valid surrogate for the progression of CKD offers some modest hope that clinical trials could be undertaken that would be feasible using this endpoint [24]. As for the albumin: creatinine ratio or urine: protein ratio in the urine, there is considerable controversy over wether or not this endpoint is a valid surrogate. In general, small reductions in urine albumin in the range of $300 \mathrm{mg} / \mathrm{g}$ down to $30 \mathrm{mg} / \mathrm{g}$ are probably not indicative of major changes in clinical cardiorenal outcomes. However, in patients with diabetic CKD with heavy proteinuria (> $1 \mathrm{~g}$ urine protein per day), a large reduction (30-50\%) may be a large enough signal that $\mathrm{CKD}$ is stabilizing, therefore influencing the future risk of cardiovascular events such as heart failure and the need for renal replacement therapy or all-cause mortality [34]. Of note, the Study Of Diabetic Nephropathy With Atrasentan (SONAR) trial testing low dose atrasentan (endothelin receptor A antagonist) has a unique design that will also test the validity of urine protein as a surrogate in patients with diabetic nephropathy (eGFR 25 to $75 \mathrm{~mL} / \mathrm{min} / 1.73 \mathrm{~m}^{2}$ and a urine albumin creatinine ratio (UACR) $300-5,000 \mathrm{mg} / \mathrm{g}$ [35]. In this trial, all subjects $(\mathrm{N}=4148)$ are given atrasentan $0.75 \mathrm{mg}$ p.o. qd initially and then are characterized as "responders" who experience a $30 \%$ or more reduction in urine protein. Then both the "responders" and "nonresponders" are randomized to atrasentan or placebo for several years with a composite renal endpoint: doubling of serum creatinine (confirmed by a 30-day serum creatinine) or the onset of end stage renal disease (needing chronic dialysis or renal transplantation or renal death). If only the responders benefit from the study drug for the clinical outcomes, then proteinuria will be validated as a surrogate. However if both the responders and nonresponders either benefit or both fail to benefit over placebo, then the uncertainty around the surrogacy of proteinuria as a treatment target will continue.

\section{Agents to Prevent and Control Hyperkalemia}

Patiromer calcium and sodium zirconium cyclosilicate are two new oral potassium binders expected to be approved and in clinical use shortly (Figure 3) [36]. Patiromer calcium is a novel exchange resin formulated as beads that contain sorbitol as an adjunctive cathartic which accounts for $50 \%$ of weight $(2 \mathrm{~g}$ sorbitol for every $4.2 \mathrm{~g}$ of patiromer) as well as calcium ( $1.6 \mathrm{~g}$ calcium for every $4.2 \mathrm{~g}$ of patiromer). Patiromer is insoluble in typical solvents and passes through the GI tract without degradation and has its principal site of potassium in the colon about 7 hours after ingestion. The Polymeric Potassium Binder, in a Double-blind, Placebo-controlled Study in Patients with Chronic Heart Failure (PEARL-HF) demonstrated that in HF patients with hyperkalemia randomized to patiromer calcium were more successfully treated with spironolactone $50 \mathrm{mg} /$ day (91\% vs $74 \%$ placebo; $\mathrm{P}=.019)[37,38]$.

In the Patiromer for the Treatment of Hyperkalemia (OPALHK) study, patients with CKD and eGFR $15-59 \mathrm{~mL} / \mathrm{min} / 1.73 \mathrm{~m}^{2}$ who were on at least one ACEI, ARB, or MRA, and had serum potassium concentrations of 5.1-6.4 mEq/L at two screenings were eligible for the trial. In the first part of the trial, 91 subjects with potassium concentrations 5.1-5.4 mEq/L received open-label patiromer $4.2 \mathrm{~g} \mathrm{PO}$ bid titrated up to average daily dose of $12.8 \mathrm{~g}$ and those $(\mathrm{n}=151)$ with baseline potassium concentrations $5.5-6.4 \mathrm{mEq} / \mathrm{L}$ received double the dose ( $8.4 \mathrm{~g}$ PO b.i.d. titrated up to $21.4 \mathrm{~g}$ average daily dose) for 4 weeks. The maximum dose of patiromer allowed was $50.4 \mathrm{~g} /$ day (12, $4.2 \mathrm{~g}$ packets). Patiromer resulted in baseline to week 4 potassium reduction (primary outcome) of $-1.01 \pm 0.03 \mathrm{mEq} / \mathrm{L}(\mathrm{P}<.001)$. The median change in the potassium concentration from the start of a randomized withdrawal phase out to 4 weeks was $+0.72 \mathrm{mEq} / \mathrm{L}$ in the placebo group and $0 \mathrm{mEq} / \mathrm{L}$ in the patiromer group receiving an average daily dose of $21.1 \mathrm{~g}$, demonstrating extended suppression of potassium concentrations in the plasma.

Sodium zirconium cyclosilicate (ZS-9, ZS Pharma, Inc) is another novel agent under development as a treatment for acute and long-term chronic hyperkalemia. Sodium zirconium cyclosilicate is an inorganic cation exchanger engineered to have a highly selective, high-capacity crystalline lattice structure to preferentially entrap monovalent cations (specifically excess potassium ions) over divalent cations (e.g., calcium

\section{Patiromer Calcium}

- Organic polymer

-2-Propenoic acid, 2-fluoro-, calcium salt

(2:1), polymer with diethenylbenzene

- and 1,7-octadiene

- Cross-linked polymer of calcium 2-

fluoroprop-2-enoate with

diethenylbenzene

- and octa-1,7-diene

\section{Sodium Zirconium Cyclosilicate (ZS-9)}

\author{
-Inorganic polymer, selective potassium trap \\ -Octahedral [ZrO6]2- \\ Units confers \\ negative \\ Charge to the framework, enabling \\ Cation exchange
}

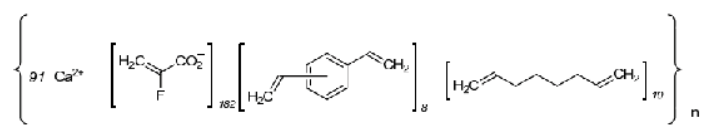

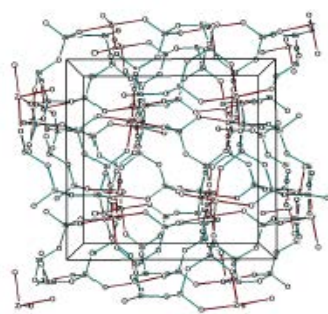

Figure 3: Novel potassium binders approaching approval and use in practice. 
and magnesium). Sodium zirconium cyclosilicate also appears to bind ammonium resulting in net acid loss and systemic elevation in plasma bicarbonate. In a double-blind, placebo-controlled clinical trial in patients with hyperkalemia ( $66 \%$ on at least one ACEI, ARB, or MRA), a total of 753 patients with potassium levels $5.0-6.5 \mathrm{mEq} / \mathrm{L}$, which included patients with CKD, heart failure, diabetes, and those on ACEIs, ARBs, or MRAs, were randomized to receive 1 of 4 doses of sodium zirconium cyclosilicate versus placebo [39]. At 48 hours, there were absolute mean reductions of $0.73 \mathrm{mEq} / \mathrm{L}$ in the 10 -g group $(\mathrm{P}<0.0001)$, as compared with a mean reduction of $0.25 \mathrm{mEq} / \mathrm{L}$ in the placebo group. The mean reduction from baseline to 1 hour after the first 10 -g dose of sodium zirconium cyclosilicate was $0.11 \mathrm{mEq} / \mathrm{L}(\mathrm{P}=$ .009) suggesting a potassium binding effect in the upper gastrointestinal tract at the level of the stomach and proximal small intestine. A total of 543/753 patients $(72.1 \%)$ achieved a normal serum potassium of $3.5-4.9 \mathrm{mEq} / \mathrm{L}$ during the initial 48 hour phase, and proceeded to the randomized extended use phase which demonstrated significantly lower potassium levels with zirconium cyclosilicate $5 \mathrm{~g}$ and $10 \mathrm{~g}$ daily versus the placebo for up to 12 days.

In a second multicenter trial, 258 stable outpatients with a potassium concentration $\geq 5.1 \mathrm{mEq} / \mathrm{L}$ (range $5.1-7.1 \mathrm{meq} / \mathrm{L})$ at baseline $(\sim 67 \%$ on at least one ACEI, ARB, or MRA), received $10 \mathrm{~g}$ of zirconium cyclosilicate $\mathrm{PO}$ t.i.d. during the initial 48-hour open-label phase. Patients achieving normokalemia $(3.5-5.0 \mathrm{mEq} / \mathrm{L})$ were randomized to receive sodium zirconium cyclosilicate, $5 \mathrm{~g}$ ( $\mathrm{n}=45$ patients), $10 \mathrm{~g}$ ( $\mathrm{n}$ $=51)$, or $15 \mathrm{~g}(\mathrm{n}=56)$, or placebo $(\mathrm{n}=85)$ daily for 28 days [40]. The rates of achieving normokalemia at 24 and 48 hours were 84 and $98 \%$, respectively. The primary end point was the mean serum potassium levels between placebo and each treatment group (highest to lowest) during days 8 through 29 of the randomized phase which was achieved for all doses of zirconium cyclosilicate versus placebo. The proportion of patients with normokalemia during the randomized phase of the study was significantly higher in all zirconium cyclosilicate groups vs. placebo $(80 \%, 90 \%$, and $94 \%$ for the $5 \mathrm{~g}, 10 \mathrm{~g}$, and $15 \mathrm{~g}$ groups, vs. $46 \%$ with placebo; $\mathrm{P}<.001$ for each dose vs. placebo). Thus it appears that there will be two new products available in the near future to aide with the management of hyperkalemia in patients with acute and chronic CRS where the use of ACE, ARB, and MRA could be facilitated with better control of serum potassium.

\section{AcuteCardiorenalSyndromes RequiringHospitalization}

Unlike the ambulatory setting, the acute hospitalization of a patient with chronic cardiorenal disease presents considerable risks for acute kidney injury, decompensation of heart failure, need for the intensive care unit, prolonged hospital stay, ESRD, and death. In the schema of five subtypes of CRS, the acute syndromes are Type 1 (cardiac decompensation leading to AKI), Type 3 (AKI leading to HF), and Type 5 (simultaneous cardiac and renal failure in sepsis, etc). In almost all circumstances, the acute CRS involve a complex and multifaceted pathophysiology of acute on chronic heart and kidney disease as shown in Figure 4. Unfortunately, there are no approved therapies that have been shown to reduce or attenuate the degree of acute/injury to both the heart and kidneys. Many acute therapies have been tested in clinical trials, but all have failed to improve outcomes in a convincing fashion,

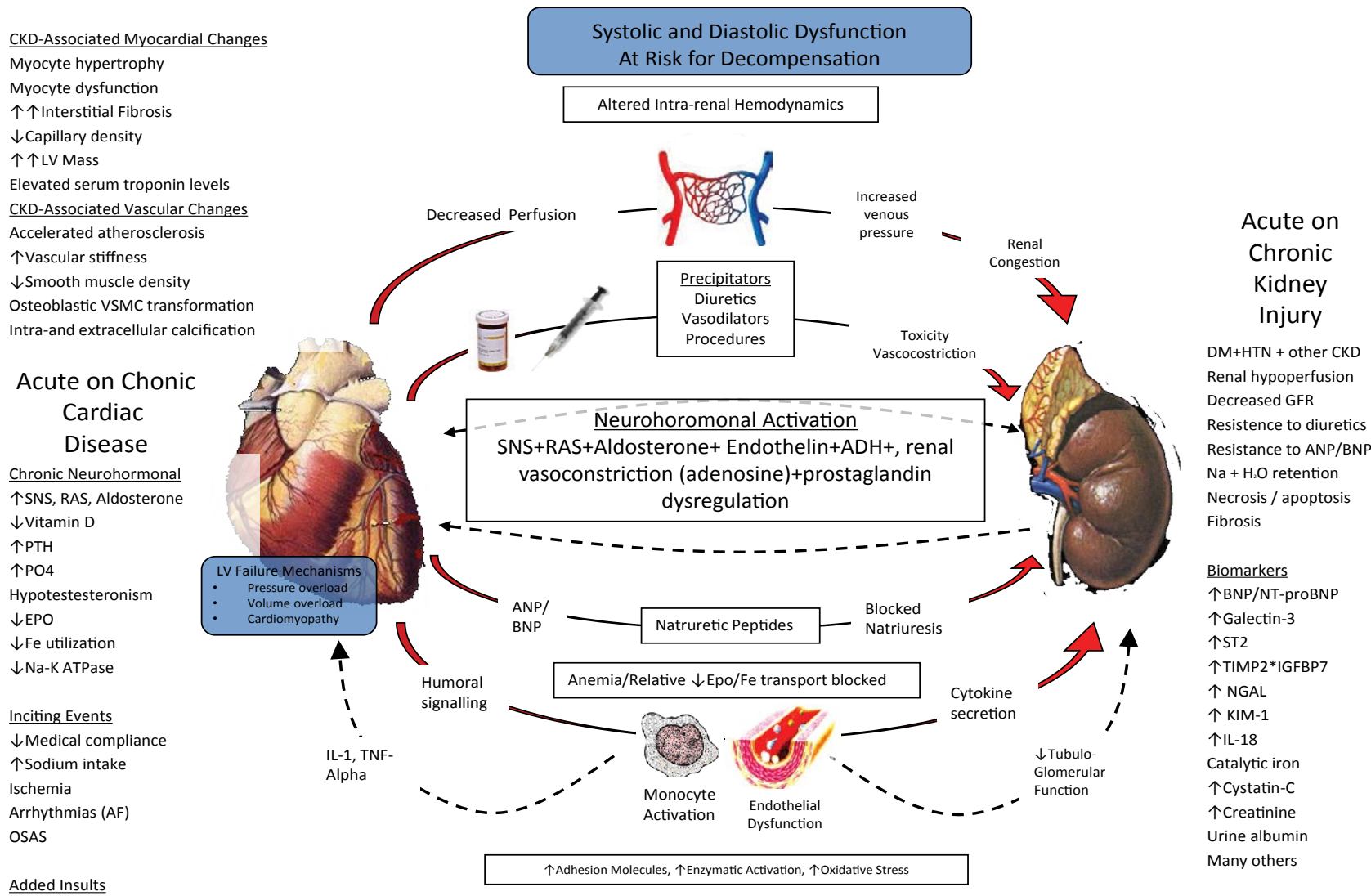

Added Insults

NSAIDS, TZDs, DPP4 Inhibitors

Figure 4: Pathogenesis of acute CRS (type 1 and 3). 
including inotropic agents, inodilators, rolophyilline, endothelin receptor antagonists, arginine vasopressin antagonist, and human recombinant BNP. Additionally, among the conventional therapies available to physicians, strategies proven to improve outcomes have been difficult to indentify. Clinical trials have shown that the use of lowdose dopamine, high-dose or continuous infusion of loop diuretics, and ultrafiltration have not broadly benefitted patients at risk or with incipient CRS. The heterogeneity of responses in these studies suggests we have not developed adequate approaches to target those patients that are most likely to benefit (and least likely to be harmed) in our clinical trials [41]. As a result, clinical practice in the hospital setting has not changed much over the past decade with respect to cardiorenal patients. Therefore, we believe that there is a considerable opportunity to develop new vistas in this field to advance the understanding and care for this population. Most of this opportunity will be dependent on phenotypic characterization of the CRS with respect to predominant mechanism (cell signaling, neurohormonal, hemodynamic, electrolyte imbalance) and then a specific therapy applied to the major mechanism. It is unlikely that a "one size fits all" approach to any novel agent in acute development will be broadly successful, including agents such as serelaxin (analogue to the pregnancy hormone relaxin) and omecamtiv mecarbil (myosin activator inotropic agent) [42,43]. A shortcoming of the trials programs for both of these agents is a 48 hour infusion which is simply not long enough to have a meaningful impact on decompensated cardiac or renal function with respect to any of the major mechanisms of acute organ failure. A more realistic approach would be a prolonged infusion ( 5 or more days) and then conversion to subcutaneous or oral therapy in analogy to the use of antibiotics, corticosteroids, or anticoagulation [44].

\section{Acute Kidney Injury}

The definition of acute kidney injury (AKI ) was unified by the Kidney Disease Global Outcomes Initiative (KDIGO) in a set of guidelines that incorporated prior AKI definitions by the Acute Kidney Injury Network (AKIN) and the Risk, Injury, Failure, Loss, and EndStage Kidney Disease (RIFLE) classifications. The KDIGO criteria for
AKI (based on the rise in serum creatinine and urine output shown in Figure 5) were helpful to the practice and research community in setting a standard for recognition of acute dysfunction and a baseline definition from which future modifications can be made as have been done for acute myocardial infarction. A list of selected biomarkers for AKI is shown in Table 2. There have been many studies that have shown that independently and together, a rise in serum creatinine (threshold $\geq 0.3 \mathrm{mg} / \mathrm{dl}$ ) or a reduction in urine output (threshold < $0.5 \mathrm{cc} / \mathrm{kg} / \mathrm{hr}$ for six hours) is prognostic for the development of more serious renal events such as permanent loss of renal filtration function, ESRD, rehospitalization, and death. However, many of these subtle changes in renal status can be due to transient hemodynamic changes and not damage or death of functional renal parenchymal cells. Thus, the advent of markers of acute tubular injury has represented a major advance in the early detection and confirmation of AKI (Figure 6). Because serum creatinine can take 48 hours to significantly rise, the recognition of AKI based on creatinine is always delayed. While urine output can abruptly decline in AKI, it is commonly manipulated by intravenous fluid administration and use of diuretics. Hence, urine output cannot be a reliable indicator of AKI alone and can be misleading in many cases. However, in the setting of oliguria, it has been shown that a "renal stress test" with a one-time administration of high-dose furosemide can be prognostic for the short-term outcome of ESRD or death [45].

Novel markers that are indicators of tubular cell-cycle arrest (tissue inhibitor of metalloproteinase-2 [TIMP-2], insulin-like growth factor binding protein-7 [IGFBP-7]), protectors against catalyticiron induced oxidative stress (siderocalin-2 or neutrophil gelatinase associated lipocalin), or promotors of tubular cell recovery (kidney injury molecule-1) have all been shown to be assistive in the diagnosis and prognosis of AKI. In addition, cytosolic enzymes and housekeeping proteins involved in normal cell biologic functions such as alpha and pie-glutathione S-transferase, L-type fatty acid binding protein, and F-isoprostanes can indicate tubular cell injury or death. Increased urinary levels of proteins normally reabsorbed by the proximal tubules can also indicate tubular dysfunction including urinary albumin,
Based on Serum Creatinine and Urine Output
Based on Damage Biomarkers

TIMP2*IGFBP7, NGAL, L-FABP, KIM-1, IL-18

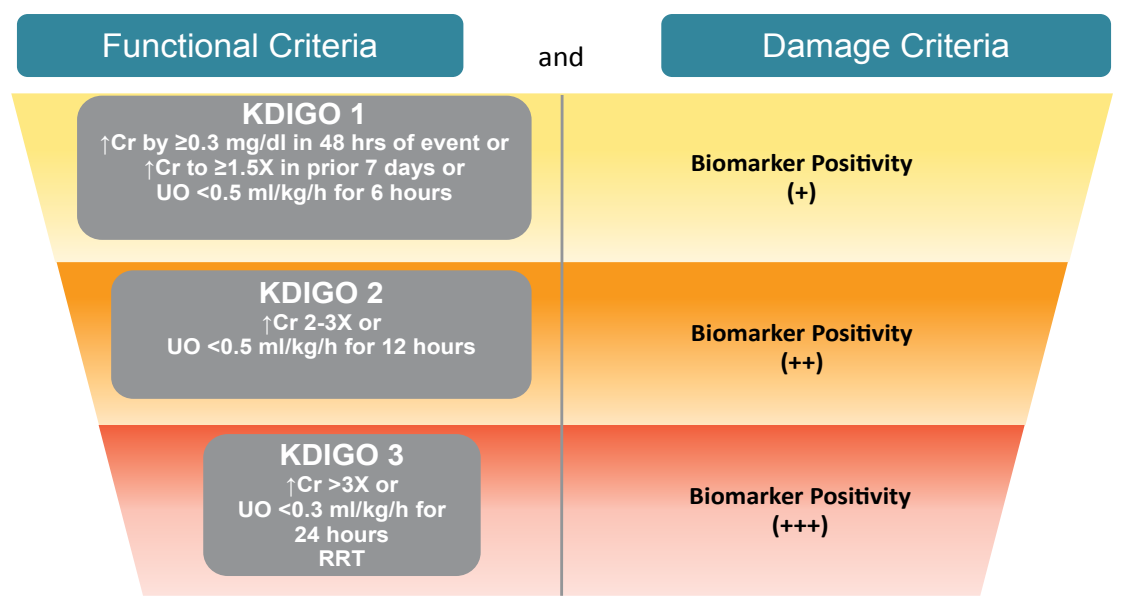

Figure 5: Schema for integrating functional and injury markers for AKI. 
Citation: McCullough PA, Tumlin JA, Szerlip H, Vijayaraghavan K, Jyothinagaram S, et al. (2015) Cardiorenal Syndromes: Advances in Determining Diagnosis, Prognosis, and Therapy. J Cardiovasc Dis Diagn 3: 221. doi: 10.4172/2329-9517.1000221

Page 13 of 28

\begin{tabular}{|c|c|c|c|c|c|c|c|c|}
\hline Biomarkers & Current Status & $\begin{array}{l}\text { Biological and } \\
\text { Pathophysiological } \\
\text { Properties }\end{array}$ & $\begin{array}{l}\text { Measurable in } \\
\text { Plasma, Serum or } \\
\text { Blood }\end{array}$ & $\begin{array}{l}\text { Measurable in } \\
\text { Urine }\end{array}$ & $\begin{array}{l}\text { In Vitro } \\
\text { Diagnostic } \\
\text { Target }^{\S}\end{array}$ & $\begin{array}{l}\text { Potential } \\
\text { Clinical Utility } \\
\text { and Guided } \\
\text { Therapeutic } \\
\text { Targets }\end{array}$ & $\begin{array}{l}\text { Characteristic } \\
\text { Features }\end{array}$ & References \\
\hline \multicolumn{9}{|l|}{ Cardiac specific } \\
\hline Cardiac troponin $\mathrm{I}^{\dagger}$ & $\begin{array}{l}\text { FDA approved } \\
\text { qualification for } \\
\text { nonclinical use. }\end{array}$ & $\begin{array}{l}\text { cTnl is inhibitory } \\
\text { component of } \\
\text { troponin complex } \\
\text { which controls } \\
\text { muscle contraction } \\
\text { by suppressing } \\
\text { interaction between } \\
\text { actin and myosin. } \\
\text { cTnl is released } \\
\text { into the blood due } \\
\text { to myocardial injury } \\
\text { (necrosis and } \\
\text { apoptosis). }\end{array}$ & $\begin{array}{l}\text { Serum cTnl } \\
\text { immunoassay }\end{array}$ & No & $\begin{array}{l}\text { Early changes } \\
\text { of heart genes } \\
\text { in drug-induced } \\
\text { cardiotoxicity; } \\
\text { Proteomics has } \\
\text { higher accuracy } \\
\text { than troponins } \\
\text { in drug-induced } \\
\text { cardiotoxicity. }\end{array}$ & $\begin{array}{l} \\
\\
\text { Diagnostic and } \\
\text { monitoring } \\
\text { AMl and peri- } \\
\text { operative } \\
\text { myocardial } \\
\text { damage } \\
\text { (cardiac } \\
\text { transplantation, } \\
\text { cardiac by- } \\
\text { pass, cardiac } \\
\text { dysfunction, } \\
\text { congestive } \\
\text { heart failure); } \\
\text { Possibly } \\
\text { for anti- } \\
\text { ischemic and } \\
\text { cytoprotective } \\
\text { therapies by the } \\
\text { Ca2 }{ }^{+} \text {-sensitizer, } \\
\text { which targets } \\
\text { cTnC. The } \\
\text { interaction } \\
\text { between cTnl } \\
\text { and cTnC } \\
\text { mediated by } \\
\text { Ca2 }{ }^{+} \text {triggers } \\
\text { muscle } \\
\text { contraction, } \\
\text { whereby leading } \\
\text { to positive } \\
\text { inotropes } \\
\text { function. } \\
\text { No guided } \\
\text { therapeutic } \\
\text { targets so far. } \\
\\
\end{array}$ & $\begin{array}{l}\text { A highly } \\
\text { specific } \\
\text { for acute } \\
\text { myocardial } \\
\text { injury; } \\
\text { A highly } \\
\text { sensitive ( limit } \\
\text { of detection } 3 \text { or } \\
<3 \text { pg/mL); } \\
\text { A predictive, } \\
\text { robust, reliable } \\
\text { marker; } \\
\text { Age-relative } \\
\text { marker: } \\
\text { Baseline cTnl is } \\
\text { higher in normal } \\
\text { adult (> } 60 \\
\text { years-old) than } \\
\text { that in younger } \\
\text { (< } 60 \text { years- } \\
\text { old). Baseline } \\
\text { troponins } \\
\text { are higher in } \\
\text { healthy infants } \\
\text { than those in } \\
\text { adults; cTnl is } \\
\text { not fully within } \\
\text { the human } \\
\text { myocardium } \\
\text { until } 9 \text { months } \\
\text { of age. } \\
\text { Gender-relative } \\
\text { marker (higher } \\
\text { in man than } \\
\text { female). } \\
\text { Note: Increased } \\
\text { troponins may } \\
\text { result from } \\
\text { non-cardiac } \\
\text { conditions, } \\
\text { such as renal } \\
\text { damage or } \\
\text { septic shock. }\end{array}$ & [77-80] \\
\hline Cardiac Troponin $\mathrm{T}^{\dagger}$ & $\begin{array}{l}\text { FDA approved } \\
\text { its qualification } \\
\text { for nonclinical } \\
\text { use. } \\
\text { FDA cleared } \\
\text { as a prognostic } \\
\text { aid for all-cause } \\
\text { mortality in } \\
\text { ESRD }\end{array}$ & $\begin{array}{l}\text { cTnT services to } \\
\text { attach the complex } \\
\text { to tropomyosin and } \\
\text { acts a complex } \\
\text { signal amplifier. } \\
\text { cTnT is released } \\
\text { into the blood due } \\
\text { to myocardial injury } \\
\text { (necrosis and } \\
\text { apoptosis). }\end{array}$ & Serum cTnT (ELISA) & & & $\begin{array}{l}\text { No guided } \\
\text { therapeutic } \\
\text { targets so far. }\end{array}$ & $\begin{array}{l}\text { A highly } \\
\text { specific } \\
\text { for acute } \\
\text { myocardial } \\
\text { injury; } \\
\text { A highly } \\
\text { sensitive } \\
\text { ( a second } \\
\text {-generation } \\
\text { cardiospecific } \\
\text { assay, Elecys, } \\
\text { Roche } \\
\text { Diagnostics); } \\
\text { A predictive, } \\
\text { robust, reliable } \\
\text { marker. }\end{array}$ & [77-80] \\
\hline
\end{tabular}


Citation: McCullough PA, Tumlin JA, Szerlip H, Vijayaraghavan K, Jyothinagaram S, et al. (2015) Cardiorenal Syndromes: Advances in Determining Diagnosis, Prognosis, and Therapy. J Cardiovasc Dis Diagn 3: 221. doi: 10.4172/2329-9517.1000221

Page 14 of 28

\begin{tabular}{|c|c|c|c|c|c|c|c|c|}
\hline Galectin- $3^{\dagger}$ & $\begin{array}{l}\text { FDA cleared as } \\
\text { a prognostic aid } \\
\text { for HF outcomes } \\
\text { (hospitalization } \\
\text { and death) } \\
\text { reflects interstitial } \\
\text { fibrosis that is } \\
\text { different from } \\
\text { NT-proBNP } \\
\text { (loading marker) } \\
\text { in response to } \\
\text { ventricular stress. }\end{array}$ & $\begin{array}{l}\text { Macrophage-derived } \\
\text { Gal-3 induces } \\
\text { cardiac fibroblast } \\
\text { proliferation and } \\
\text { collage deposition } \\
\text { in development } \\
\text { and process of HF. } \\
\text { Secretion of Gal-3 } \\
\text { is via a pathway in } \\
\text { which cytosolic Gal- } \\
3 \text { shifts to plasma } \\
\text { membrane and } \\
\text { integrates in vesicles } \\
\text { extruding from } \\
\text { plasma membrane. }\end{array}$ & $\begin{array}{l}\text { Plasma, ELISA } \\
\text { (BG medicine, Inc., } \\
\text { USA). }\end{array}$ & No & No & $\begin{array}{l}\text { Therapeutic } \\
\text { potential. Pts } \\
\text { with HF. }\end{array}$ & $\begin{array}{l}\text { Predicting } \\
\text { prognosis for } \\
\text { outcome of HF } \\
\text { and preserved } \\
\text { LVEF; } \\
\text { A good } \\
\text { biomarker" } \\
\text { (AUC-ROC = } \\
0.66-0.67 \text { ) and } \\
\text { for acute HF } \\
\text { (AUC-ROC } \\
=0.74 \text { ). } \\
\text { Note: baseline } \\
\text { levels, Plasma, } \\
\text { higher in older } \\
\text { and women. }\end{array}$ & {$[27,80-82]$} \\
\hline $\begin{array}{l}\text { B-type natriuretic } \\
\text { peptide }\end{array}$ & $\begin{array}{l}\text { Established and } \\
\text { FDA cleared as } \\
\text { a diagnostic, } \\
\text { prognostic, and } \\
\text { management aid } \\
\text { in patients with } \\
\text { suspected and } \\
\text { confirmed acute } \\
\text { and chronic HF }\end{array}$ & $\begin{array}{l}\text { A hormone secreted } \\
\text { by cardiac ventricles } \\
\text { in response to } \\
\text { excessive stretching } \\
\text { of cardiomyocytes. } \\
\text { They are released in } \\
\text { pts with acute HF. }\end{array}$ & Plasma: ELISA & No & No & $\begin{array}{l}\text { Identifying pts } \\
\text { with any degree } \\
\text { of cardiac } \\
\text { dysfunction; } \\
\text { Identifying pts } \\
\text { at increased } \\
\text { risk for sudden } \\
\text { death; } \\
\text { Helping } \\
\text { clinicians } \\
\text { in planning } \\
\text { discharge of HF } \\
\text { pts; } \\
\text { Therapeutic } \\
\text { targets: HF } \\
\text { in elderly pts, } \\
\text { significant } \\
\text { different from } \\
\text { standard } \\
\text { therapy. }\end{array}$ & $\begin{array}{l} \\
\text { A high } \\
\text { sensitivity and } \\
\text { accuracy. } \\
\text { Concentration } \\
\text { of }>100 \text { pg/ } \\
\text { mL diagnosed } \\
\text { HF with a } 90 \% \\
\text { sensitivity and } \\
76 \% \text { specificity. }\end{array}$ & {$[79,80,83]$} \\
\hline $\begin{array}{l}\text { N-terminal Pro- } \\
\text { B-type natriuretic } \\
\text { Peptide }\end{array}$ & $\begin{array}{l}\text { An emerging } \\
\text { marker of } \\
\text { diagnosis, } \\
\text { prognosis and } \\
\text { prognosis of } \\
\text { acute HF. }\end{array}$ & $\begin{array}{l}\text { Secretion due to } \\
\text { myocardial stretch } \\
\text { and increased wall } \\
\text { stress. }\end{array}$ & Plasma ELISA & & & $\begin{array}{l}\text { Therapeutic } \\
\text { targets: HF } \\
\text { in elderly pts, } \\
\text { statistically } \\
\text { significant } \\
\text { different from } \\
\text { standard } \\
\text { therapy. }\end{array}$ & $\begin{array}{l}\text { Cutoff value } \\
\text { of } 1,078 \mathrm{pg} / \mathrm{mL} \\
\text { for NT-proBNP } \\
\text { had greatest } \\
\text { prognostic } \\
\text { accuracy, } \\
\text { however no } \\
\text { consistent } \\
\text { cutpoint in the } \\
\text { literature due } \\
\text { to influence of } \\
\text { renal clearance. }\end{array}$ & {$[79,80,82]$} \\
\hline $\begin{array}{l}\text { Creatine kinase } \\
\text { myocardial band }\end{array}$ & $\begin{array}{l}\text { An older marker } \\
\text { of cardiac } \\
\text { damage in pts } \\
\text { with cardiac } \\
\text { surgery }\end{array}$ & $\begin{array}{l}\text { CK-MB released } \\
\text { from damaged } \\
\text { myocardium. A } \\
\text { higher level reduces } \\
\text { cardiac reserve at } \\
\text { baseline and result } \\
\text { in hemodynamic } \\
\text { instability, whereby } \\
\text { they lead to greater } \\
\text { risk of postsurgical } \\
\text { AKI. }\end{array}$ & $\begin{array}{l}\text { Beckman Coulter } \\
\text { Access II instrument } \\
\text { for CK-MB. }\end{array}$ & No & No & $\begin{array}{l}\text { Prediction of } \\
\text { postoperative } \\
\text { AKI in children } \\
\text { with cardiac } \\
\text { surgery }\end{array}$ & $\begin{array}{l}\text { A good } \\
\text { biomarker" } \\
\text { (AUC-ROC for } \\
\text { CK-MB = 0.77). }\end{array}$ & [84] \\
\hline $\begin{array}{l}\text { Heart-fatty acid } \\
\text { binding protein }\end{array}$ & $\begin{array}{l}\text { An emerging } \\
\text { marker of pts } \\
\text { with cardiac } \\
\text { surgery }\end{array}$ & $\begin{array}{l}\text { h-FABP released } \\
\text { from damaged } \\
\text { myocardium. A } \\
\text { higher level reduces } \\
\text { cardiac reserve at } \\
\text { baseline and result } \\
\text { in hemodynamic } \\
\text { instability, whereby } \\
\text { they lead to greater } \\
\text { risk of postsurgical } \\
\text { AKI. }\end{array}$ & $\begin{array}{l}\text { Evidence } \\
\text { Investigator } \\
\text { Cytokine Custom } \\
\text { Array for h-FABP. }\end{array}$ & No & No & $\begin{array}{l}\text { Prediction of } \\
\text { postoperative } \\
\text { AKI in children } \\
\text { with cardiac } \\
\text { surgery }\end{array}$ & $\begin{array}{l}\text { A good } \\
\text { biomarker" } \\
\text { (AUC-ROC = } \\
0.78)\end{array}$ & [84] \\
\hline $\begin{array}{l}\text { Suppressor of } \\
\text { Tumorigenicity-2 }\end{array}$ & & $\begin{array}{l}\text { Decoy protein for IL- } \\
33 \text { receptor family, a } \\
\text { potential mediator of } \\
\text { myocardial fibrosis. }\end{array}$ & $\begin{array}{l}\text { Soluble form of } \\
\text { ST2 for serum } \\
\text { measurement } \\
\text { plasma ELISA }\end{array}$ & & & $\begin{array}{l}\text { No guided } \\
\text { therapeutic } \\
\text { targets so far. }\end{array}$ & & {$[80]$} \\
\hline
\end{tabular}


Citation: McCullough PA, Tumlin JA, Szerlip H, Vijayaraghavan K, Jyothinagaram S, et al. (2015) Cardiorenal Syndromes: Advances in Determining Diagnosis, Prognosis, and Therapy. J Cardiovasc Dis Diagn 3: 221. doi: 10.4172/2329-9517.1000221

Page 15 of 28

\begin{tabular}{|c|c|c|c|c|c|c|c|c|}
\hline \multicolumn{9}{|l|}{ Cardiorenal specific } \\
\hline$\beta-2$ microglobulin & $\begin{array}{l}\text { An emerging } \\
\text { marker of CRS. }\end{array}$ & $\begin{array}{l}\beta 2 \mathrm{M} \text { involving GFR, } \\
\text { tissue turnover, and } \\
\text { inflammation. }\end{array}$ & $\begin{array}{l}\text { Plasma b2M } \\
\text { (ELISA). }\end{array}$ & No & No & $\begin{array}{l}\text { Acute or chronic } \\
\text { HF subjects }\end{array}$ & $\begin{array}{l}\boldsymbol{\beta} 2 \mathrm{M} \text { services } \\
\text { as dual role's } \\
\text { marker for } \\
\text { cardiac and } \\
\text { renal function } \\
\text { and failure. } \\
\text { A sensitive } \\
\text { marker of } \beta 2 \mathrm{M} . \\
\text { Plasma levels of } \\
\beta 2 \mathrm{M} \text { significant } \\
\text { higher in CHF } \\
\text { pts than in } \\
\text { ATL and AH } \\
\text { subjects; } \\
\text { Strong positive } \\
\text { correlation } \\
\text { between } \beta 2 \mathrm{M} \\
\text { and TMIP1 in } \\
\text { CHF pts and AH } \\
\text { subjects versus } \\
\text { ATL; } \\
\text { Strong positive } \\
\text { correlation } \\
\text { between } \beta 2 \mathrm{M} \\
\text { with NT-proBNP } \\
\text { and GER values } \\
\text { in CHF pts; } \\
\text { Strong positive } \\
\text { correlations } \\
\text { between levels } \\
\text { of b2M and } \\
\text { TIMP1 and } \\
\text { severity of } \\
\text { cardiorenal } \\
\text { remodeling and } \\
\text { failure. }\end{array}$ & [85] \\
\hline $\begin{array}{l}\text { Tissue inhibitor of } \\
\text { metalloproteinase }-1\end{array}$ & $\begin{array}{l}\text { An emerging } \\
\text { marker of CRS. }\end{array}$ & $\begin{array}{l}\text { TIMP1 inhibiting } \\
\text { matrix degradation } \\
\text { and over-expressing } \\
\text { in substitutive } \\
\text { fibrosis }\end{array}$ & $\begin{array}{l}\text { Plasma TIMP1 } \\
\text { (Automatic analyzer, } \\
\text { AxSym; Abbott) }\end{array}$ & No & $\begin{array}{l}\text { Gene (TIMP1) } \\
\text { specific for rat } \\
\text { (qPCR). }\end{array}$ & $\begin{array}{l}\text { CHF pts or } \mathrm{AH} \\
\text { subjects }\end{array}$ & $\begin{array}{l}\text { A sensitive } \\
\text { marker of } \\
\text { TIMP1. } \\
\text { Plasma levels } \\
\text { of TIMP1 } \\
\text { significant } \\
\text { higher in CHF } \\
\text { pts than in } \\
\text { ATL and AH } \\
\text { subjects; } \\
\text { Strong positive } \\
\text { correlation } \\
\text { between b2m } \\
\text { and TMIP1 in } \\
\text { CHF pts and AH } \\
\text { subjects versus } \\
\text { ATL; } \\
\text { Strong positive } \\
\text { correlation } \\
\text { between b2M } \\
\text { with NT-proBNP } \\
\text { and GER values } \\
\text { in CHF pts; } \\
\text { Strong positive } \\
\text { correlations } \\
\text { between levels } \\
\text { of b2M and } \\
\text { TIMP1 and } \\
\text { severity of } \\
\text { cardiorenal } \\
\text { remodeling and } \\
\text { failure. }\end{array}$ & [85] \\
\hline
\end{tabular}


Citation: McCullough PA, Tumlin JA, Szerlip H, Vijayaraghavan K, Jyothinagaram S, et al. (2015) Cardiorenal Syndromes: Advances in Determining Diagnosis, Prognosis, and Therapy. J Cardiovasc Dis Diagn 3: 221. doi: 10.4172/2329-9517.1000221

Page 16 of 28

\begin{tabular}{|c|c|c|c|c|c|c|c|c|}
\hline $\begin{array}{l}\text { C-type natriuretic } \\
\text { peptide }\end{array}$ & $\begin{array}{l}\text { An emerging } \\
\text { new diagnostic } \\
\text { and prognostic } \\
\text { marker }\end{array}$ & $\begin{array}{l}\text { Renal-derived CNP } \\
\text { suppresses fibroblast } \\
\text { proliferation and } \\
\text { collage production; } \\
\text { Hypoxia, cytokines, } \\
\text { and fibrotic growth } \\
\text { factors stimulate its } \\
\text { production; Urinary } \\
\text { CNP reflects renal } \\
\text { structural remodeling } \\
\text { prior to kidney } \\
\text { disease, and detects } \\
\text { in pts with acute } \\
\text { compensated HF. }\end{array}$ & No & Yes & $\begin{array}{l}\text { Increased } \\
\text { CNP mRNA } \\
\text { expression in } \\
\text { diabetic rat } \\
\text { kidney. CNP } \\
\text { holds promise } \\
\text { for diagnostic } \\
\text { and therapeutic } \\
\text { targets. }\end{array}$ & $\begin{array}{l}\text { Pts with HF and } \\
\text { renal disease } \\
\text { states }\end{array}$ & $\begin{array}{l}\text { CNP service as } \\
\text { a double role's } \\
\text { marker for heart } \\
\text { failure and renal } \\
\text { remodeling } \\
\text { (involving } \\
\text { tubulointerstitial } \\
\text { fibrosis). }\end{array}$ & [86-88] \\
\hline \multicolumn{9}{|l|}{ Renal specific } \\
\hline \multicolumn{9}{|l|}{ Glomerulus-specific } \\
\hline Albumin ${ }^{\dagger}$ & $\begin{array}{l}\text { FDA approved } \\
\text { qualification for } \\
\text { nonclinical use. }\end{array}$ & $\begin{array}{l}\text { A most abundant } \\
\text { protein in blood } \\
\text { plasma that functions } \\
\text { as a regulator of } \\
\text { colloidal osmotic } \\
\text { pressure of blood. } \\
\text { Dysfunction of } \\
\text { glomerular filtration } \\
\text { leads to increased } \\
\text { levels of Alb } \\
\text { measured in blood } \\
\text { and urine }\end{array}$ & No & Yes & No & No & $\begin{array}{l}\text { In pts with } \\
\text { cisplatin } \\
\text { treatment, } \\
\text { urinary excretion } \\
\text { of } \mathrm{Alb}>20 \mathrm{mg} / \mathrm{L} \text {. }\end{array}$ & [89] \\
\hline Total urine protein ${ }^{\dagger}$ & $\begin{array}{l}\text { FDA approved } \\
\text { TUP qualification } \\
\text { for preclinical } \\
\text { use. }\end{array}$ & $\begin{array}{l}\text { Increased total } \\
\text { urinary proteins are } \\
\text { due to dysfunction } \\
\text { of glomerular } \\
\text { filtration and tubular } \\
\text { reabsorption. }\end{array}$ & No & Urine & No & No & $\begin{array}{l}\text { Correlation } \\
\text { of increased } \\
\text { amounts with } \\
\text { diabetes or } \\
\text { drug-induced } \\
\text { nephrotoxicity. }\end{array}$ & [89] \\
\hline a1-microglobulin & $\begin{array}{l}\text { An emerging } \\
\text { marker of AKI. }\end{array}$ & $\begin{array}{l}\text { A protein that is } \\
\text { synthesized in } \\
\text { liver with half of } \\
\text { circulated bound } \\
\text { to IgA complex. Its } \\
\text { free form is filtrated } \\
\text { by glomerulus and } \\
\text { reabsorbed by } \\
\text { proximal tubular } \\
\text { cells. }\end{array}$ & No & Urine (ELISA) & No & $\begin{array}{l}\text { Pts with post- } \\
\text { cardiac surgery } \\
\text { and ATN. }\end{array}$ & $\begin{array}{l}\text { A sensitive } \\
\text { marker for } \\
\text { proximal tubular } \\
\text { dysfunction in } \\
\text { pts with cardiac } \\
\text { surgery. } \\
\text { A prognostic } \\
\text { marker of } \\
\text { outcome in pts } \\
\text { with nonoliguric } \\
\text { acute tubular } \\
\text { necrosis. } \\
\text { A useful marker } \\
\text { of tubular } \\
\text { dysfunction in } \\
\text { infants at high } \\
\text { risk of AKI. }\end{array}$ & [90] \\
\hline$\beta-2$ microglobulin $^{\dagger}$ & $\begin{array}{l}\text { FDA approved } \\
\text { qualification for } \\
\text { nonclinical use. }\end{array}$ & $\begin{array}{l}\text { A protein present on } \\
\text { all nucleated cells. } \\
\text { Increased levels of } \\
\text { urine B2M indicate } \\
\text { dysfunction of } \\
\text { glomerular filtration } \\
\text { and reabsorption of } \\
\text { proximal tubules. }\end{array}$ & Yes & Yes & $\begin{array}{l}\text { Gene specific for } \\
\text { rat (qPCR). }\end{array}$ & No & $\begin{array}{l}\text { Increased levels } \\
\text { of B2M in pts } \\
\text { with idiopathic } \\
\text { membrane } \\
\text { nephropathy, } \\
\text { in pts suffering } \\
\text { from with drug- } \\
\text { induced kidney } \\
\text { damage, and } \\
\text { in transplant } \\
\text { pts with acute } \\
\text { tubulointerstitial } \\
\text { rejection. }\end{array}$ & [89] \\
\hline
\end{tabular}


Citation: McCullough PA, Tumlin JA, Szerlip H, Vijayaraghavan K, Jyothinagaram S, et al. (2015) Cardiorenal Syndromes: Advances in Determining Diagnosis, Prognosis, and Therapy. J Cardiovasc Dis Diagn 3: 221. doi: 10.4172/2329-9517.1000221

\begin{tabular}{|c|c|c|c|c|c|c|c|c|}
\hline Cystatin $\mathrm{C}^{\dagger}$ & $\begin{array}{l}\text { FDA and EMA } \\
\text { approved its } \\
\text { qualification for } \\
\text { preclinical use } \\
\text { of drug-induced } \\
\text { AKI. }\end{array}$ & $\begin{array}{l}\text { A low molecular } \\
\text { weight protein, which } \\
\text { is freely filtrated } \\
\text { through glomerulus } \\
\text { and completely by } \\
\text { tubular cells. CysC } \\
\text { strongly related to } \\
\text { GER. }\end{array}$ & Yes & Yes & $\begin{array}{l}\text { Gene specific for } \\
\text { rat (qPCR). }\end{array}$ & $\begin{array}{l}\text { Pts with acute } \\
\text { HF or cardiac } \\
\text { surgery. }\end{array}$ & $\begin{array}{l}\text { An early } \\
\text { urinary marker } \\
\text { for detecting AKI } \\
\text { within } 6 \text { hrs after } \\
\text { cardiac surgery. } \\
\text { A high } \\
\text { sensitive } \\
\text { marker to } \\
\text { detect type } 1 \\
\text { CRS. } \\
\text { An excellent } \\
\text { biomarkerl } \\
\text { (AUC = 0.92). } \\
\text { Serum cutoff } \\
\text { values >0.3mg/ } \\
\text { dL: specificity } \\
\text { of } 90 \% \text { and } \\
\text { sensitivity of } \\
77 \% \text { for AKI ; } \\
\text { Controversy: } \\
\text { Serum CysC } \\
\text { is superior to } \\
\text { urinary CysC. } \\
\text { Serum CysC is } \\
\text { not in relation } \\
\text { to age, gender, } \\
\text { race or muscle } \\
\text { mass. }\end{array}$ & {$[79,89,91]$} \\
\hline $\begin{array}{l}\text { Interferon inducible } \\
\text { protein-10 }\end{array}$ & $\begin{array}{l}\text { An emerging of } \\
\text { marker of AKI. }\end{array}$ & $\begin{array}{l}\text { A protein that } \\
\text { is secreted by } \\
\text { several cell types in } \\
\text { response to IFN-y. } \\
\text { It plays roles in } \\
\text { chemottraction for } \\
\text { immune effector cells } \\
\text { and in promotion of } \\
\text { T cell adhesion to } \\
\text { endothelial cells. }\end{array}$ & No & $\begin{array}{l}\text { Microbead- } \\
\text { based sandwich } \\
\text { ELISA }\end{array}$ & $\begin{array}{l}\text { In human it is } \\
\text { encoded by } \\
C X C L 10 \text { gene. }\end{array}$ & Pts with AKI. & $\begin{array}{l}\text { A sensitive } \\
\text { and specific } \\
\text { marker of AKI } \\
\text { (sensitivity } \\
\text { of } 85 \% \text { and } \\
\text { specificity of } \\
80 \% \text { in pts with } \\
\text { AKI vs. healthy } \\
\text { individuals). } \\
\text { A good marker } \\
\text { of AKI (AUC- } \\
\text { ROC }=0.89 \text { ) }\end{array}$ & [90] \\
\hline \multicolumn{9}{|c|}{ Proximal tubular-specific (also including TUP, $\alpha 1 \mathrm{M}, \beta 2 \mathrm{M}, \mathrm{CysC}$ ) } \\
\hline $\begin{array}{l}\text { Kidney injury } \\
\text { molecule- } 1^{\ddagger}\end{array}$ & $\begin{array}{l}\text { FDA and EMEA } \\
\text { approved its } \\
\text { qualification for } \\
\text { preclinical use of } \\
\text { drug-induced AKI }\end{array}$ & $\begin{array}{l}\text { Kim-1is a } \\
\text { transmembrane } \\
\text { glycoprotein with an } \\
\text { immunoglobulin and } \\
\text { mucin domain. It is } \\
\text { induced in response } \\
\text { to ischemia or toxic } \\
\text { injury. }\end{array}$ & No & Urine (ELISA) & No & $\begin{array}{l}\text { Pts with } \\
\text { acute HF or } \\
\text { receiving by- } \\
\text { pass surgery or } \\
\text { catheterization. }\end{array}$ & $\begin{array}{l}\text { The first injury } \\
\text { marker of kidney } \\
\text { toxicity qualified } \\
\text { by FDA and } \\
\text { EMEA. } \\
\text { A highly } \\
\text { sensitive } \\
\text { marker. } \\
\text { An excellent } \\
\text { biomarker" } \\
\text { (AUC-ROC: } \\
\text { KIM-1=0.91- } \\
0.99 \text { ). } \\
\text { A highly } \\
\text { specific for } \\
\text { ischemic AKI. } \\
\text { An early marker } \\
\text { for predicting } \\
\text { AKI within 2-24 } \\
\text { hrs after post } \\
\text { cardiopulmonary } \\
\text { bypass. }\end{array}$ & {$[79,91,92]$} \\
\hline
\end{tabular}


Citation: McCullough PA, Tumlin JA, Szerlip H, Vijayaraghavan K, Jyothinagaram S, et al. (2015) Cardiorenal Syndromes: Advances in Determining Diagnosis, Prognosis, and Therapy. J Cardiovasc Dis Diagn 3: 221. doi: 10.4172/2329-9517.1000221

\begin{tabular}{|c|c|c|c|c|c|c|c|c|}
\hline $\begin{array}{l}\text { Kidney injury } \\
\text { molecule- } 1^{¥}\end{array}$ & $\begin{array}{l}\text { An emerging } \\
\text { blood marker } \\
\text { of } \mathrm{AKI}\end{array}$ & $\begin{array}{l}\text { Release of KIM-1 } \\
\text { into the blood is due } \\
\text { to loss of polarity } \\
\text { of injured tubular } \\
\text { cells, increased } \\
\text { transepithelial } \\
\text { permeability, and } \\
\text { altered microvasculr } \\
\text { permeability. }\end{array}$ & Plasma or serum & Yes & No & AKI pts. & $\begin{array}{l}\text { A specific } \\
\text { and sensitive } \\
\text { marker for AKI. } \\
\text { Plasma KIM-1 } \\
\text { were higher in } \\
\text { AKI pts than in } \\
\text { controls or post- } \\
\text { cardiac surgery } \\
\text { pts without AKI. } \\
\text { An excellent } \\
\text { biomarker" } \\
\text { (AUC-ROC } \\
=0.98 \text { ). } \\
\text { In pts of } \\
\text { cardiopulmonary } \\
\text { bypass, plasma } \\
\text { KIM-1 increased } \\
\text { within } 2 \text { days } \\
\text { after surgery } \\
\text { only in pts with } \\
\text { AKI. }\end{array}$ & [70] \\
\hline Clusterin $^{\dagger}$ & $\begin{array}{l}\text { FDA approved } \\
\text { qualification for } \\
\text { nonclinical use. }\end{array}$ & $\begin{array}{l}\text { Clu as a glycoprotein } \\
\text { involved in cell } \\
\text { adhesion, membrane } \\
\text { remodeling, } \\
\text { apoptosis inhibition, } \\
\text { phagocyte } \\
\text { recruitment. } \\
\text { Ischemia, unilateral } \\
\text { obstruction or drug } \\
\text { insult leads to } \\
\text { increased Clu levels. }\end{array}$ & No & Yes & $\begin{array}{l}\text { Gene specific for } \\
\text { rat (qPCR). }\end{array}$ & $\begin{array}{l}\text { Increased } \\
\text { mRAN } \\
\text { expression } \\
\text { identified in } \\
\text { drug-treated } \\
\text { animals. }\end{array}$ & $\begin{array}{l}\text { Immnostaining } \\
\text { showed over } \\
\text { expressed } \\
\text { Clu on human } \\
\text { kidney } \\
\text { specimens } \\
\text { from pts with } \\
\text { polycystic } \\
\text { kidney disease, } \\
\text { acute and } \\
\text { chronic renal } \\
\text { transplant } \\
\text { rejection. }\end{array}$ & [89] \\
\hline $\begin{array}{l}\text { a-glutathione } \\
\text { S-transferase }\end{array}$ & $\begin{array}{l}\text { An emerging } \\
\text { marker of AKI. }\end{array}$ & $\begin{array}{l}\text { The tubular enzyme } \\
\text { is released from } \\
\text { proximal or distal } \\
\text { tubular cells and } \\
\text { correlated with } \\
\text { severity of damaged } \\
\text { cells. }\end{array}$ & No & $\begin{array}{l}\text { Urine (ELISA) } \\
\text { (Biotrin Ltd, } \\
\text { Dublin, Ireland } \\
\text { for a-GST). }\end{array}$ & No & $\begin{array}{l}\text { Early } \\
\text { intervention } \\
\text { can significantly } \\
\text { improve } \\
\text { the dismal } \\
\text { prognosis. }\end{array}$ & $\begin{array}{l}\text { A good } \\
\text { biomarker" } \\
\text { (AUC-ROC of } \\
0.893) .\end{array}$ & [94] \\
\hline $\begin{array}{l}\text { Neutrophil } \\
\text { gelatinase } \\
\text { associated lipocalin }\end{array}$ & $\begin{array}{l}\text { An existing } \\
\text { marker for acute } \\
\text { renal tubular } \\
\text { injury. }\end{array}$ & $\begin{array}{l}\text { NGAL is a small } \\
25-k D a \text { protein } \\
\text { and belongs to the } \\
\text { lipocalin family of } \\
\text { proteins. Plasma } \\
\text { NGAL is fully filtered } \\
\text { through glomerulus } \\
\text { and totally } \\
\text { reabsorbed in the } \\
\text { tubules. }\end{array}$ & Serum or plasma & Urine (ELISA) & No & $\begin{array}{l}\text { Possible as } \\
\text { iron chelator } \\
\text { because } \\
\text { bacteriostasis } \\
\text { of NGAL } \\
\text { by forming } \\
\text { complex with } \\
\text { iron-binding } \\
\text { siderophores. } \\
\text { Pts with acute } \\
\text { decompensated } \\
\text { HF; Estimating } \\
\text { risk of early } \\
\text { worning renal } \\
\text { function. }\end{array}$ & $\begin{array}{l}\text { A sensitive } \\
\text { marker, but is } \\
\text { not a kidney- } \\
\text { specific marker } \\
\text { (its synthesis } \\
\text { by extrarenal } \\
\text { tissues and } \\
\text { neutrophils). } \\
\text { An early } \\
\text { predictor of } \\
\text { subclinical } \\
\text { AKI (within } 2 \mathrm{~h} \text { ) } \\
\text { Elevated plasma } \\
\text { NGAL with a } \\
\text { cutoff value } \\
\text { of } 170 \text { ng/mL } \\
\text { detecting type } \\
1 \mathrm{CRS} \text { within } \\
48-72 \mathrm{~h} \text {. Serum } \\
\text { NGAL } \geq 140 \mathrm{ng} / \\
\mathrm{mL} \text { had a } 7.4 \\
\text { fold higher risk } \\
\text { to develop WRF. } \\
\text { Urinary NGAL } \\
\text { is not reliable. } \\
\text { Compared with } \\
\text { serum NGAL. }\end{array}$ & {$[79,91]$} \\
\hline
\end{tabular}


Citation: McCullough PA, Tumlin JA, Szerlip H, Vijayaraghavan K, Jyothinagaram S, et al. (2015) Cardiorenal Syndromes: Advances in Determining Diagnosis, Prognosis, and Therapy. J Cardiovasc Dis Diagn 3: 221. doi: 10.4172/2329-9517.1000221

Page 19 of 28

\begin{tabular}{|c|c|c|c|c|c|c|c|c|}
\hline $\begin{array}{l}\mathrm{N} \text {-acetyl- } \beta \text {-D- } \\
\text { glucosaminidase }\end{array}$ & $\begin{array}{l}\text { An emerging } \\
\text { marker of AKI. }\end{array}$ & $\begin{array}{l}\text { NAG is a lysosomal } \\
\text { brush border enzyme } \\
\text { in proximal tubular } \\
\text { cells. It sheds into } \\
\text { urine in response } \\
\text { to tubular injury } \\
\text { induced by contrast } \\
\text { media, toxins, and } \\
\text { ischemia. }\end{array}$ & No & Yes & No & $\begin{array}{l}\text { Pts receiving } \\
\text { cardiac surgery. }\end{array}$ & $\begin{array}{l}\text { Increased } \\
\text { urinary NAG } \\
\text { in pts with } \\
\text { cardiac surgery } \\
\text { to develop } \\
\text { postoperative } \\
\text { AKI. } \\
\text { A good } \\
\text { biomarker" } \\
\text { (AUC-ROC of } \\
0.863) \text {. }\end{array}$ & {$[79,91,93]$} \\
\hline Interleukin-18 & $\begin{array}{l}\text { An emerging } \\
\text { diagnostic } \\
\text { marker for AKI. }\end{array}$ & $\begin{array}{l}\text { IL-18 is a } \\
\text { proinflammatory } \\
\text { cytokine derived } \\
\text { from proximal } \\
\text { tubular cells. The } \\
\text { interaction between } \\
\text { inflammasome } \\
\text { and other proteins } \\
\text { induces an } \\
\text { inflammatory } \\
\text { response. Urinary IL- } \\
18 \text { can be detected } \\
\text { after acute proximal } \\
\text { tubular damage. }\end{array}$ & Yes & Urine (ELISA) & No & No & $\begin{array}{l}\text { A sensitive } \\
\text { marker. } \\
\text { An excellent } \\
\text { biomarker" } \\
\text { (AUC-ROC = > } \\
90 \text { for ischemic } \\
\text { AKI). } \\
\text { An early } \\
\text { marker: } \\
\text { increased levels } \\
48 \text { h prior to } \\
\text { the increase } \\
\text { in serum } \\
\text { creatinine. } \\
\text { IL-18 is not } \\
\text { kidney-specific } \\
\text { marker. }\end{array}$ & {$[79,91,65]$} \\
\hline Trefoil factor $3^{\dagger}$ & $\begin{array}{l}\text { FDA approved } \\
\text { TFF3qualification } \\
\text { for preclinical } \\
\text { use. }\end{array}$ & $\begin{array}{l}\text { TFF3 (intestinal } \\
\text { trefoil factor) is } \\
\text { a protein that is } \\
\text { secretory product } \\
\text { of mucin producing } \\
\text { cells. It plays a } \\
\text { role in epithelial } \\
\text { restitution. within GI } \\
\text { tract and it correlates } \\
\text { with downregulation } \\
\text { of IL-6 and IL-8 in } \\
\text { human intestinal } \\
\text { epithelial cells. }\end{array}$ & No & Urine & No & No & $\begin{array}{l}\text { No report of } \\
\text { clinical study. }\end{array}$ & [89] \\
\hline $\begin{array}{l}\text { L-type fatty acid } \\
\text { binding protein }\end{array}$ & $\begin{array}{l}\text { An emerging, } \\
\text { promising } \\
\text { marker. }\end{array}$ & $\begin{array}{l}\text { FABP is located in } \\
\text { proximal tubular cells } \\
\text { and plays a role in } \\
\text { reduction of cellular } \\
\text { oxidant stress. } \\
\text { Ischemia leads to } \\
\text { reduction of L-FABP } \\
\text { via proximal tubular } \\
\text { reabsorption. }\end{array}$ & No & Urine (ELISA) & No & $\begin{array}{l}\text { Pts receiving } \\
\text { cardiac surgery }\end{array}$ & $\begin{array}{l}\text { High sensitivity } \\
\text { and specificity } \\
\text { to detect AKI in } \\
\text { pts with cardiac } \\
\text { surgery. }\end{array}$ & [91] \\
\hline $\begin{array}{l}\text { ח- glutathione } \\
\text { S-transferase }\end{array}$ & $\begin{array}{l}\text { An emerging } \\
\text { marker of AKI. }\end{array}$ & $\begin{array}{l}\text { The tubular enzyme } \\
\text { is released from } \\
\text { proximal or distal } \\
\text { tubular cells and } \\
\text { correlated with } \\
\text { severity of damaged } \\
\text { cells. }\end{array}$ & No & $\begin{array}{l}\text { Urine (ELISA) } \\
\text { (Biotrin Ltd, } \\
\text { Dublin, Ireland } \\
\text { for } \alpha \text {-GST). }\end{array}$ & No & $\begin{array}{l}\text { Early } \\
\text { intervention } \\
\text { can significantly } \\
\text { improve } \\
\text { the dismal } \\
\text { prognosis. }\end{array}$ & $\begin{array}{l}\begin{array}{l}\text { An excellent } \\
\text { biomarker" } \\
\text { (AUC-ROC of } \\
0.929) .\end{array} \\
\end{array}$ & [93] \\
\hline $\begin{array}{l}\text { Y glutamyl } \\
\text { transpeptidase }\end{array}$ & $\begin{array}{l}\text { An emerging } \\
\text { marker of AKI. }\end{array}$ & $\begin{array}{l}\text { The tubular enzyme } \\
\text { is released from } \\
\text { proximal or distal } \\
\text { tubular cells and } \\
\text { correlated with } \\
\text { severity of damaged } \\
\text { cells. }\end{array}$ & No & Urine (ELISA) & No & $\begin{array}{l}\text { Early } \\
\text { intervention } \\
\text { can significantly } \\
\text { improve } \\
\text { the dismal } \\
\text { prognosis. }\end{array}$ & $\begin{array}{l}\text { An excellent } \\
\text { biomarkerll } \\
\text { (AUC-ROC of } \\
0.95) .\end{array}$ & [93] \\
\hline $\begin{array}{l}\text { Alkaline } \\
\text { phosphatase }\end{array}$ & $\begin{array}{l}\text { An emerging } \\
\text { marker of AKI. }\end{array}$ & $\begin{array}{l}\text { The tubular enzyme } \\
\text { is released from } \\
\text { proximal or distal } \\
\text { tubular cells and } \\
\text { correlated with } \\
\text { severity of damaged } \\
\text { cells. }\end{array}$ & No & Urine (ELISA) & No & $\begin{array}{l}\text { Early } \\
\text { intervention. } \\
\text { can significantly } \\
\text { improve } \\
\text { the dismal } \\
\text { prognosis }\end{array}$ & $\begin{array}{l}\text { A good } \\
\text { biomarker" } \\
\text { (AUC-ROC of } \\
0.863) .\end{array}$ & [93] \\
\hline
\end{tabular}


Citation: McCullough PA, Tumlin JA, Szerlip H, Vijayaraghavan K, Jyothinagaram S, et al. (2015) Cardiorenal Syndromes: Advances in Determining Diagnosis, Prognosis, and Therapy. J Cardiovasc Dis Diagn 3: 221. doi: 10.4172/2329-9517.1000221

Page 20 of 28

\begin{tabular}{|c|c|c|c|c|c|c|c|c|}
\hline $\begin{array}{l}\text { Retinol binding } \\
\text { protein }\end{array}$ & $\begin{array}{l}\text { An emerging of } \\
\text { marker of AKI. }\end{array}$ & $\begin{array}{l}\text { A protein that is } \\
\text { synthesized in liver. } \\
\text { It is freely filtrated } \\
\text { by glomerulus and } \\
\text { reabsorbed by } \\
\text { proximal tubule. }\end{array}$ & No & Urine (ELISA) & No & $\begin{array}{l}\text { Pts with } \\
\text { AKI and } \\
\text { nephrotoxicity. }\end{array}$ & $\begin{array}{l}\text { A highly } \\
\text { sensitive } \\
\text { indicator of } \\
\text { proximal tubular } \\
\text { dysfunction in } \\
\text { pts with AKI. } \\
\text { An early } \\
\text { diagnostic } \\
\text { marker of } \\
\text { drug-induced } \\
\text { nephrotoxicity } \\
\text { in pts. }\end{array}$ & [92] \\
\hline Fetuin A & $\begin{array}{l}\text { An emerging of } \\
\text { marker of AKI. }\end{array}$ & $\begin{array}{l}\text { A protein that s } \\
\text { synthesized in liver } \\
\text { and plays role in } \\
\text { regulation of insulin } \\
\text { activity, response to } \\
\text { inflammation, etc. }\end{array}$ & No & $\begin{array}{l}\text { Urine } \\
\text { (immunoblotting) }\end{array}$ & $\begin{array}{l}\text { Exosomal } \\
\text { fetuin-A } \\
\text { identified by } \\
\text { proteomics. }\end{array}$ & Pts with AKI. & $\begin{array}{l}\text { A diagnostic } \\
\text { marker of } \\
\text { AKI (urinary } \\
\text { exosomal } \\
\text { fetuin-A, EF- } \\
\text { A, was much } \\
\text { higher in ICU } \\
\text { pts with AKI } \\
\text { compared with } \\
\text { ICU pts without } \\
\text { AKI and healthy } \\
\text { volunteers). }\end{array}$ & [92] \\
\hline $\begin{array}{l}\text { Sodium-hydrogen } \\
\text { exchanger } 3\end{array}$ & $\begin{array}{l}\text { An emerging of } \\
\text { marker of AKI. }\end{array}$ & $\begin{array}{l}\text { The most abundant } \\
\text { sodium transporter } \\
\text { in renal tubules } \\
\text { that is responsible } \\
\text { for proximal } \\
\text { reabsorption of } 60-7- \\
\% \text { of filtered sodium } \\
\text { and bicarbonate. It } \\
\text { is located mainly at } \\
\text { apical membrane of } \\
\text { proximal tubular cells } \\
\text { and loop of Henle. }\end{array}$ & No & $\begin{array}{l}\text { Urine } \\
\text { (immunoblotting) }\end{array}$ & No & Pts with AKI. & $\begin{array}{l}\text { A diagnostic } \\
\text { marker of } \\
\text { tubular injury in } \\
\text { pts with AKI. }\end{array}$ & [92] \\
\hline $\begin{array}{l}\text { Cysterin-rich } \\
\text { protein-61 }\end{array}$ & $\begin{array}{l}\text { An emerging of } \\
\text { marker of AKI. }\end{array}$ & $\begin{array}{l}\text { A cysterine-rich, } \\
\text { heparin-binding } \\
\text { protein and a novel } \\
\text { ligand for integrins. } \\
\text { It is rapidly induced } \\
\text { in proximal straight } \\
\text { tubules by ischemia. }\end{array}$ & No & West blot. & No & No & $\begin{array}{l}\text { A potential } \\
\text { marker of AKI } \\
\text { (secretion of } \\
\text { urinary Cyr16 } \\
\text { within } 3-6 \text { hrs } \\
\text { after ischemia } \\
\text { in rat). } \\
\text { No clinical study } \\
\text { demonstrating } \\
\text { its use. }\end{array}$ & [92] \\
\hline Netrin-1 & $\begin{array}{l}\text { An emerging of } \\
\text { marker of AKI. }\end{array}$ & $\begin{array}{l}\text { A laminin-like protein } \\
\text { that was secreted } \\
\text { in urine within } 1 \mathrm{hr} \\
\text { following functional } \\
\text { injury and rises } \\
30-40 \text { folds in } 3 \\
\text { hrs and reaches its } \\
\text { peak in } 6 \text { hrs after } \\
\text { insult. Increase of } \\
\text { netrin- } 1 \text { in urine may } \\
\text { be due toinduction } \\
\text { of protein synthesis } \\
\text { and release of pre- } \\
\text { synthesis protein. }\end{array}$ & No & Urine & No & No & $\begin{array}{l}\text { A potential } \\
\text { universal } \\
\text { marker of } \\
\text { hypoxic } \\
\text { injury and } \\
\text { nephrotoxicity, } \\
\text { but may } \\
\text { potentially } \\
\text { applicable for } \\
\text { various AKI. } \\
\text { A prognostic } \\
\text { marker for renal } \\
\text { recovery. }\end{array}$ & [94] \\
\hline $\begin{array}{l}\text { Hepatocyte Growth } \\
\text { Factor }\end{array}$ & $\begin{array}{l}\text { An emerging of } \\
\text { marker of AKI. }\end{array}$ & $\begin{array}{l}\text { HGF is secreted by } \\
\text { mesenchymal cells } \\
\text { and acts as multi- } \\
\text { functional cytokines } \\
\text { on cells of mainly } \\
\text { epithelial cells. }\end{array}$ & No & $\begin{array}{l}\text { Microbead- } \\
\text { based sandwich } \\
\text { ELISA }\end{array}$ & No & Pts with AKI. & $\begin{array}{l}\text { A sensitive } \\
\text { and specific } \\
\text { marker of AKI } \\
\text { (sensitivity } \\
\text { of } 91 \% \text { and } \\
\text { specificity of } \\
94 \% \text { in pts with } \\
\text { AKI vs. healthy } \\
\text { individuals). } \\
\text { An excellent } \\
\text { marker" of AKI } \\
\text { (AUC-ROC = } \\
0.96)\end{array}$ & [92] \\
\hline
\end{tabular}


Citation: McCullough PA, Tumlin JA, Szerlip H, Vijayaraghavan K, Jyothinagaram S, et al. (2015) Cardiorenal Syndromes: Advances in Determining Diagnosis, Prognosis, and Therapy. J Cardiovasc Dis Diagn 3: 221. doi: 10.4172/2329-9517.1000221

Page 21 of 28

Loop of Helen-specific (also including NHE3)

Distal tubular-specific (also including Clu, NGAL, a-GST)

\begin{tabular}{|c|c|c|c|c|c|c|c|c|}
\hline CalbidinD28DK & $\begin{array}{l}\text { An emerging } \\
\text { marker of injury } \\
\text { to distal tubule } \\
\text { and colleting } \\
\text { duct. }\end{array}$ & $\begin{array}{l}\text { A vitamin } \\
\text { D-dependent } \\
\text { calcium-binding } \\
\text { protein of } 28 \mathrm{D} \text { that } \\
\text { is found in distal } \\
\text { tubules. }\end{array}$ & Serum & Urine (ELISA) & $\begin{array}{l}\text { Gene specific for } \\
\text { rat (qPCR). }\end{array}$ & No & $\begin{array}{l}\text { In pts treated } \\
\text { with cisplatin, } \\
\text { urinary } \\
\text { calbidin-D } \\
\text { levels were } \\
\text { significantly } \\
\text { increased } 8 \\
\text { days after } \\
\text { dosing. }\end{array}$ & {$[89,95]$} \\
\hline \multicolumn{9}{|c|}{ Collecting duct-specific (also including CalbidinD28DK) } \\
\hline $\begin{array}{l}\text { Renal papillary } \\
\text { antigen- } 1^{\dagger}\end{array}$ & $\begin{array}{l}\text { FDA approved } \\
\text { RPA-1 } \\
\text { qualification for } \\
\text { preclinical use. }\end{array}$ & $\begin{array}{l}\text { An uncharacterized } \\
\text { antigen that is } \\
\text { highly expressed } \\
\text { in collecting duct } \\
\text { of papillary. It } \\
\text { can be detected } \\
\text { at high levels } \\
\text { following exposure } \\
\text { to compounds that } \\
\text { induce renal papillary } \\
\text { necrosis. }\end{array}$ & No & Urine (ELISA) & No & No & $\begin{array}{l}\text { No report of } \\
\text { clinical study. }\end{array}$ & [89] \\
\hline \multicolumn{9}{|l|}{ Unknown site-specific } \\
\hline $\begin{array}{l}\text { Tissue Inhibitor of } \\
\text { Metalloproteinase- } 2^{\dagger}\end{array}$ & $\begin{array}{l}\text { An emerging } \\
\text { marker of AKI }\end{array}$ & $\begin{array}{l}\text { Involving } \\
\text { gastrointestinal cell- } \\
\text { cycle arrest process; } \\
\text { Serving as a marker } \\
\text { of cellular stress } \\
\text { induced by a variety } \\
\text { of insults. }\end{array}$ & No & $\begin{array}{l}\text { A high-sensitivity } \\
\text { cutoff value of } \\
0.3 \mathrm{ng} / / \mathrm{L}^{2} / 1000 \\
\text { for predicting } \\
\text { non-cardiac } \\
\text { surgery patients; } \\
\\
0.5 \mathrm{ng} / / \mathrm{L}^{2} / 1000 \\
\text { for predicting } \\
\text { renal recovery } \\
\text { after } \mathrm{AKI}\end{array}$ & No & $\begin{array}{l}\text { Patients with } \\
\text { cardiac surgery } \\
\text { or non-cardiac } \\
\text { surgery at risk } \\
\text { for imminent } \\
\text { AKI; } \\
\text { Patients } \\
\text { predicting renal } \\
\text { recovery from } \\
\text { AKI. }\end{array}$ & $\begin{array}{l}\text { A specific } \\
\text { marker for AKI } \\
\text { (cutoff value } \\
0.3 \text { ng//L2/1000 } \\
\text { vs. } 1.24 \text { for } \\
\text { septic, } 0.45 \text { for } \\
\text { transplant, and } \\
0.47 \text { for post- } \\
\text { hepatic surgery) } \\
\text { (cutoff value of } \\
\text { o.50 vs. } 0.81 \text { for } \\
\text { cardiac surgery) } \\
\text { A good early } \\
\text { marker (AUC- } \\
\text { ROC for AKI = } \\
0.81,4 \text { hrs after } \\
\text { cardiac surgery); } \\
\text { A good high } \\
\text { sensitive } \\
\text { marker (AUC- } \\
\text { ROC for AKI = } \\
0.85, \text { for AKI } \\
\text { stages } 2 \text { and } \\
3=0.85 \text {, for } \\
\text { early RRT use = } \\
0.83 \text {, for } 28 \text {-day } \\
\text { mortality =0.77); }\end{array}$ & [96-99] \\
\hline $\begin{array}{l}\text { TIMP-2 x Insulin- } \\
\text { like Growth Factor } \\
\text { Binding Protein } 7^{\dagger}\end{array}$ & $\begin{array}{l}\text { An emerging } \\
\text { marker of AKI }\end{array}$ & $\begin{array}{l}\text { Involving } \\
\text { gastrointestinal cell- } \\
\text { cycle arrest process; } \\
\text { Serving as a marker } \\
\text { of cellular stress } \\
\text { induced by a variety } \\
\text { of insults. }\end{array}$ & No & $\begin{array}{l}\text { A high-sensitivity } \\
\text { cutoff value of } \\
0.3 \mathrm{ng} / / \mathrm{L}^{2} / 1000 \\
\text { for predicting } \\
\text { non-cardiac } \\
\text { surgery patients; } \\
\\
0.5 \mathrm{ng} / / \mathrm{L}^{2} / 1000 \\
\text { for predicting } \\
\text { renal recovery } \\
\text { after AKI }\end{array}$ & No & $\begin{array}{l}\text { Patients with } \\
\text { cardiac surgery } \\
\text { or non-cardiac } \\
\text { surgery at risk } \\
\text { for imminent } \\
\text { AKI; } \\
\text { Patients } \\
\text { predicting renal } \\
\text { recovery from } \\
\text { AKI. }\end{array}$ & $\begin{array}{l}\text { A good reliable } \\
\text { marker (AUC- } \\
\text { ROC of TIMP-2 } \\
\text { X IGFBP7 for } \\
\text { AKI stages } 2 \text { or } \\
3=0.80) \text {. }\end{array}$ & [96-99] \\
\hline
\end{tabular}


Citation: McCullough PA, Tumlin JA, Szerlip H, Vijayaraghavan K, Jyothinagaram S, et al. (2015) Cardiorenal Syndromes: Advances in Determining Diagnosis, Prognosis, and Therapy. J Cardiovasc Dis Diagn 3: 221. doi: 10.4172/2329-9517.1000221

Page 22 of 28

\begin{tabular}{|c|c|c|c|c|c|c|c|c|}
\hline Interleukin-6 & $\begin{array}{l}\text { An emerging } \\
\text { marker of type } 1 \\
\text { CRS }\end{array}$ & $\begin{array}{l}\text { An inflammatory } \\
\text { cytokine produced } \\
\text { and secreted } \\
\text { by superoxide } \\
\text { production of } \\
\text { hydrogen peroxidase } \\
\text { and nitric oxide } \\
\text { upregulation. } \\
\text { It serves as an } \\
\text { oxidative stress } \\
\text { marker in type } 1 \\
\text { CRS. }\end{array}$ & $\begin{array}{l}\text { Plasma (ELISA) } \\
\text { (eBioscience, CA, } \\
\text { USA). }\end{array}$ & No & No & $\begin{array}{l}\text { A potential } \\
\text { therapeutic } \\
\text { target }\end{array}$ & $\begin{array}{l}\text { A diagnostic } \\
\text { marker of type } \\
1 \mathrm{CRS} \text { (IL-6 } \\
\text { levels } 90.68, \\
22.19, \text { and } 5.9 \\
\mathrm{ng} / \mathrm{mL} \text { for type } \\
1 \mathrm{CRS}, \mathrm{AHF} \\
\text { and control, } \\
\text { respectively). }\end{array}$ & [100] \\
\hline Angiotensinogen & $\begin{array}{l}\text { An emerging } \mathrm{AKI} \\
\text { marker. }\end{array}$ & $\begin{array}{l}\text { It correlates with } \\
\text { intrarenal AGT } \\
\text { angiotensin II and } \\
\text { is an indicator of } \\
\text { intrarenal RAS } \\
\text { activity }\end{array}$ & No & $\begin{array}{l}\text { Urinary (ELISA, } \\
\text { Immuno- } \\
\text { Biological } \\
\text { Laboratories Co., } \\
\text { Ltd., Japan) }\end{array}$ & No & $\begin{array}{l}\text { Predicts AKI in } \\
\text { pts with ADHF }\end{array}$ & $\begin{array}{l}\text { A good } \\
\text { specific marker } \\
\text { for AKI } \\
(A \cup C-R O C= \\
0.84) ; \\
\text { A good } \\
\text { predictive } \\
\text { marker" }(A \cup C \\
\text {-ROC }=0.79)\end{array}$ & [101] \\
\hline $\begin{array}{l}\text { Activating } \\
\text { Transcription } \\
\text { Factor3 }\end{array}$ & $\begin{array}{l}\text { An emerging } \\
\text { marker of AKI. }\end{array}$ & $\begin{array}{l}\text { A transcription } \\
\text { factor in urinary } \\
\text { exosomes. The } \\
\text { sequence of events } \\
\text { leading to formation } \\
\text { of exosomes is } \\
\text { initiated by fusing } \\
\text { of endocytic vesicle } \\
\text { with multivesisicular } \\
\text { bodies MVB), } \\
\text { forming internal } \\
\text { vesicles within MVB } \\
\text { due to invaginated } \\
\text { membrane, fusing } \\
\text { of MVB with plasma } \\
\text { membrane, and then } \\
\text { internal vesicles } \\
\text { entering extracellular } \\
\text { space as exosomes. } \\
\text { It is suggested that a } \\
\text { rich source of kidney } \\
\text { injury biomarkers } \\
\text { are present in } \\
\text { urinary exosomes } \\
\text { because they contain } \\
\text { intracellular proteins. }\end{array}$ & No & $\begin{array}{l}\text { Urine(western } \\
\text { blot) }\end{array}$ & No & Pts with AKI. & $\begin{array}{l}\text { A diagnostic } \\
\text { marker of } \\
\text { AKI pts, but in } \\
\text { normal subjects } \\
\text { or pts with CKD. } \\
\text { In ischemic (I/R) } \\
\text { and nephrotoxic } \\
\text { (cisplatin) AKI } \\
\text { rat, excretion } \\
\text { of urinary } \\
\text { exosomal } \\
\text { AFT3 was time } \\
\text { dependent. }\end{array}$ & [76] \\
\hline
\end{tabular}

* For biomarkers from preclinical biomarkers translated into clinical setting, several processes are needed, including bridging preclinical biomarkers to clinical biomarkers validation of the biomarker, transplantation application of preclinical biomarkers into clinical setting, and clinical qualification. The table includes FDA approved 10 biomarker qualification (cTnl, cTnT, Alb, B2M, Clu, CysC, TUP, TFF3, Kim-1, RPA-1) for nonclinical use. The FDA approved biomarkers are also accepted for clinical observation under certain circumstances. Qualification is a conclusion that these biomarkers are sensitive and specific biomarkers for myocardial or kidney damage. FDA also approved 3 biomarkers (Gal3, TIMP-2*IGFBP7) for clinical setting, by using Galectin-3 Assay ${ }^{\text {TM }}$ (BG Medicine) and NephroCheck ${ }^{\circledR}$ test (Astute Medical Inc., USA).

\$FDA regulates in vitro diagnostic devices (IVD), and the biomarkers used in IVD typically include genomic, proteomic, and metabolomic biomarkers.

$\dagger$ FDA approved as qualified biomarkers for nonclinical use.

${ }^{*}$ FDA and EMA qualified KIM-1 as a urinary biomarker in clinical studies on case-by case basis.

" AUC-ROC of 0.5 represents no better than expected by random change, AUC-ROC of 0.75 , a good biomarker, and AUC-ROC of 0.9 , an excellent biomarker.

\section{Biomarker abbreviations}

$\mathrm{Alb}=$ albumin; $\mathrm{AP}=$ alkaline phosphatase; $\mathrm{ATF} 3=$ activating transcription factor3; $\mathrm{BNP}=$ Brain natriuretic peptide; CK-MB = creatine kinase-MB; Clu = clusterin; CNP = C-type natriuretic peptide; cTnl = cardiac troponin I; cTnT = cardiac troponin T; Cyr61 = cysterin-rich protein; CysC = cystatin C; h-FABP = heart-type fatty acid binding protein; HGF = hepatocyte growth factor; IGFBP7 = insulin-like growth factor-binding protein 7; IL-6 = interleukin 6; IL-18 = interleukin 18; Gal-3 = galectin-3; Kim-1 = kidney injury molecule-1 (in preclinical study); KIM-1 = kidney injury molecule-1 (in human study); L-FABP = the liver type fatty acid binding protein; NAG = N-acetyl- $\beta$-Dglucosaminidase; NGAL = neutrophil gelatinase-associated lipocalin; NAG = N-acetyl-beta-D-glucosaminidase; NHE3 = sodium/hydrogen exchanger isoform;NT-proBNP = NT-pro-B type natriuretic peptide; RBP = retinol binding protein; RPA-1= renal papillary antigen-1;TFF3 = trefoil factor 3 ; TIMP-2 = tissue inhibitor of metalloproteinase 2 TUP = total urinary proteins; uAGT = urinary angiotensinogen; $\alpha$-GST = alpha-glutathione S-transferase; b2M = $\beta 2-\mathrm{Microglubin} ; \mathrm{yGT}=$ gamma glutamyl transpeptidase $\pi-G S T=\pi$-glutathione S-transferase.

Other abbreviations

$\mathrm{AKI}=$ acute kidney injury; $\mathrm{ADHF}=$ acute decompensated heart failure; $\mathrm{AH}=$ athlete's heart; $\mathrm{AHF}=$ acute heart failure; $\mathrm{AKI}=$ acute kidney injury; $\mathrm{ATL}=\mathrm{controls} ; \mathrm{AUC}=$ area under a ROC curve; $\mathrm{CHF}=$ chronic heart failure; $\mathrm{CRS}=$ cardiorenal syndrome; ELISA = enzyme-linked immunosorbent assay; EMA = European Medicines Agency; GI = gastrointestinal; GFR = glomerular filtration rate; HF = heart failure; HR = hazard ratio; LVEF = left ventricular ejection fraction; pts = Patients; RAS = rennin-angiotensin system; ROC = receiver-operating characteristic; WRF = worsening renal function; $y r=$ year

Table 2: Clinical biomarkers* used or proposed for Type 1 acute cardiorenal syndrome or type 3 acute renocardiac syndrome. 


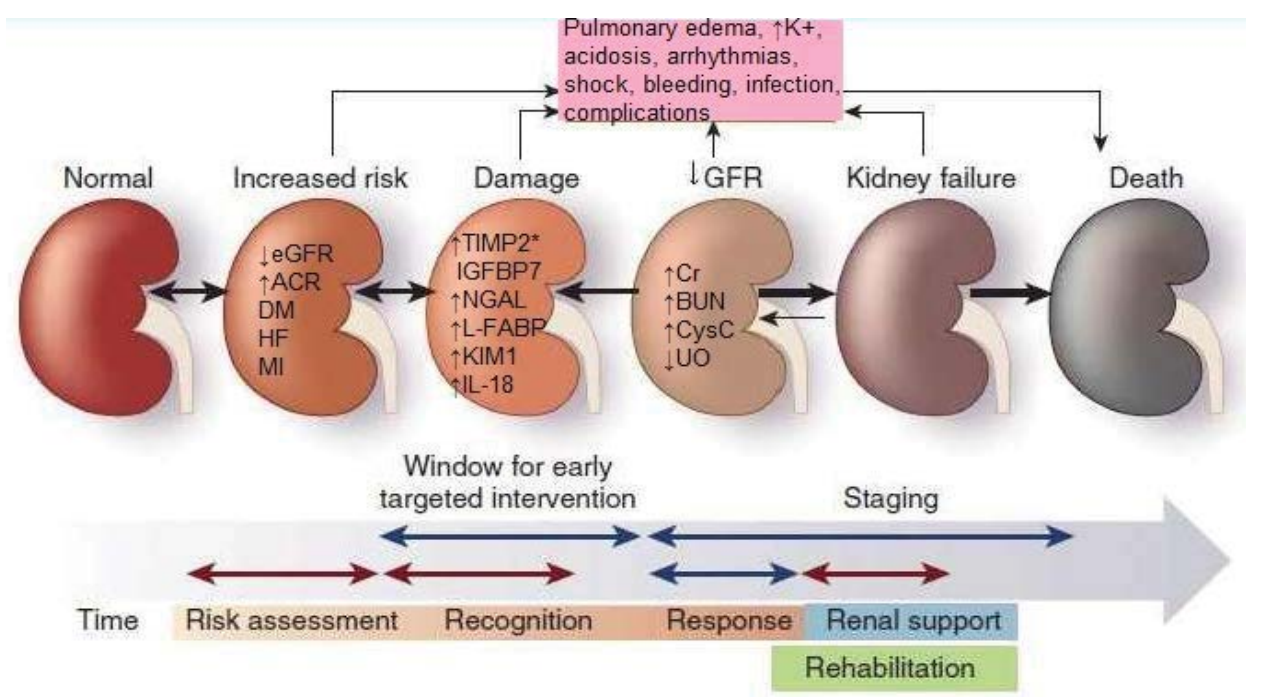

Figure 6: Continuum of kidney function in the setting of CRS.

cystatin-C, and urinary $\mathrm{N}$-acetyl-beta-D-glucosaminidase (NAG). These markers are ideally measured in the urine where they are heavily concentrated. Proteins that are constitutively upregulated in response to chronic kidney disease are less helpful (NGAL, KIM-1) clinically as the baseline value has to be considered in the interpretation of the acute value, and thus one must have multiple measurements at time points [46]. The development of commercial grade assays with the precision and reliability has been a challenge which has been recently overcome with the September, 2014 approval by the U.S. Food and Drug Administration of the NephroCheck test (Astute Medical, San Diego, CA). This test is a mathematical product of TIMP2 and IGFBP7 expressed in a unit less number with a range of 0.00 to 10.0 and a cutpoint of 0.3 as listed in the package insert. In patients admitted to the intensive care unit, a NephroCheck of $<0.3$ had a $>90 \%$ negative predictive value for the development of moderate or greater AKI [47]. The grey zone for this test appears to be 0.3 to 1.2 where there is uncertainty and likely repeat test will be needed later in time. NephroCheck values of $>2.0$ had a high positive predictive value for moderate or severe AKI and may be a future trigger for clinical actions including switching away from nephrotoxic agents (aminoglycosides, vancomycin, non-steroidal anti-inflammatory agents, etc) as well as reducing intravenous fluid administration to avoid impending volume overload that will come with reductions in urine output [48]. A novel biomarker for chronic diabetic nephropathy is urine angiotensinogen, which appears to be 5-6 fold elevated in this condition compared to controls, and appears to risk stratify for the progession of CKD in this population [49].

Thus, novel diagnostic markers will rapidly take a support position in addition to serum creatinine and urine output to: 1) rule out AKI in the setting of pre-renal azotemia, 2) confirm AKI when serum creatinine and urine output are subjective, and 3) serve as a harbinger for moderate or severe AKI to develop over the following 12 to 48 hours in the intensive care unit [50]. Importantly, biomarkers for Type $5 \mathrm{CRS}$, while probably not helpful in recognizing the clinical condition, may be a critical step forward in the identification of cell, tissue, or organ-specific protective strategies against overwhelming injury. Table 3 gives select biomarkers under investigation for Type 5 CRS. A future hopeful vista for cardiorenal disease is the idea that early detection can lead to strategies that prevent or attenuate renal injury/dysfunction or enhance renal recovery and lead to improved outcomes (Figure 7).

\section{Future Trials and the Need for Continuous Measures of Disease Progression}

Acute and chronic CRS do not have specific groups of symptoms that can be used to evaluate benefit of therapies; hence, we have been left to conduct clinical trials with binary endpoints such as the doubling of serum creatinine, ESRD, hospitalization, and death as outcomes. These trials are large, have to be broadly inclusive, and in general have failed to allow the clinical development of products in the hospital and clinic setting. They have been fraught with problems including competing risks (e.g. death before the opportunity to demonstrate and organ effect) and lack of control of concurrent therapies (Figure 8). In addition, the renal functional reserve, or the ability of the kidney to adapt to a decreased mass of functioning nephrons and still carry out filtration sufficiently to keep the plasma pool of creatinine in a reasonable range, makes the assessment of CKD difficult. Renal functional reserve often dictates weather AKI will become clinically recognized in the setting of an acute renal stress such as AHF or sepsis. Hence there has been little opportunity for benefit and considerable opportunity for off-target harmful effects (Figure 8). There has been approximately 10 years with no new disease modifying agents to offer patients with CRS. Thus, despite the concern over the legitimacy of surrogate outcomes, reliable continuous clinical measures are needed that precede hard clinical outcomes in order for the field to progress. Other specialities have witnessed progress with such surrogates as human immunodeficiciency viral load, hepatitis viral load, hemoglobin A1 C, low-density lipoprotein cholesterol, and stages of disease progression in malignancies. So the pursuit of trusted biomarkers and other integrated measures of disease progression are crucial to the future of cardiorenal medicine. In addition, subgroup analyses, as well as more sophisticated approaches to identify heterogeneity of treatment benefit (and harm) should be pursued, and tested in confirmatory trials. These efforts should reduce the time course of development and implementation of beneficial therapies. Continued efforts on safety observations and registries can aide in assuring freedom from unexpected events over prolonged use as well as in the calculus in risk benefit tradeoffs. 
Citation: McCullough PA, Tumlin JA, Szerlip H, Vijayaraghavan K, Jyothinagaram S, et al. (2015) Cardiorenal Syndromes: Advances in Determining Diagnosis, Prognosis, and Therapy. J Cardiovasc Dis Diagn 3: 221. doi: 10.4172/2329-9517.1000221

Page 24 of 28

\begin{tabular}{|c|c|c|c|c|c|c|c|c|}
\hline Biomarkers & Current Status & $\begin{array}{l}\text { Biological and } \\
\text { Physiological } \\
\text { Properties }\end{array}$ & $\begin{array}{l}\text { Measurable in } \\
\text { Plasma, Serum or } \\
\text { Blood }\end{array}$ & $\begin{array}{l}\text { Measurable } \\
\text { in Urine }\end{array}$ & $\begin{array}{l}\text { In Vitro } \\
\text { Diagnostic } \\
\text { Target }^{\S}\end{array}$ & $\begin{array}{l}\text { Potential } \\
\text { Clinical Utility } \\
\text { and Guided } \\
\text { Therapeutic } \\
\text { Targets }\end{array}$ & $\begin{array}{l}\text { Characteristic } \\
\text { Features }\end{array}$ & References \\
\hline \multicolumn{9}{|c|}{ Cardiorenal specific } \\
\hline $\begin{array}{l}\text { B-type natriuretic } \\
\text { peptide, albumin }\end{array}$ & $\begin{array}{l}\text { New combined } \\
\text { markers for type } \\
5 \text { CRS. }\end{array}$ & $\begin{array}{l}\text { Central (aortic) } \\
\text { hemodynamic as a } \\
\text { key factor relating to } \\
\text { end-organ damage. It } \\
\text { can be demonstrated } \\
\text { by close relationship } \\
\text { between BNP and } \\
\text { microalbuminuria, } \\
\text { eGFR, aortic } \\
\text { pressure, and pulse } \\
\text { wave velocity. }\end{array}$ & $\begin{array}{l}\text { Plasma BNP } \\
\text { immunoassay } \\
\text { (Architect; Abbott and } \\
\text { Lumipulse Presto, } \\
\text { Tokyo, Japan). }\end{array}$ & No & No & $\begin{array}{l}\text { Potential } \\
\text { therapeutic } \\
\text { target via } \\
\text { controlling central } \\
\text { hemodynamic. }\end{array}$ & $\begin{array}{l}\text { A diagnostic marker } \\
\text { of simultaneous cardiac } \\
\text { and renal damage/ } \\
\text { dysfunction in pts with } \\
\text { hypertension (positive } \\
\text { correlation of BNP with } \\
\text { UACR, aortic pulse } \\
\text { pressure and negative } \\
\text { correlation of BNP with } \\
\text { eGFR). }\end{array}$ & [102] \\
\hline Multibiomarkesr & $\begin{array}{l}\text { A proposed } \\
\text { panel marker of } \\
\text { type } 5 \text { CRS }\end{array}$ & $\begin{array}{l}\text { Literature-reviewed } \\
\text { proposal }\end{array}$ & $\begin{array}{l}\text { It is dependent on } \\
\text { what marker used. }\end{array}$ & $\begin{array}{l}\text { It is } \\
\text { dependent } \\
\text { on marker } \\
\text { used. }\end{array}$ & No & $\begin{array}{l}\text { Potential } \\
\text { therapeutic } \\
\text { intervention. }\end{array}$ & $\begin{array}{l}\text { Using severe sepsis } \\
\text { and septic shock as } \\
\text { a model of type } 5 \\
\text { CRS, it is suggested } \\
\text { that several panels } \\
\text { of biomarkers could } \\
\text { serve as markers of } \\
\text { simultaneous AKI } \\
\text { and acute cardiac } \\
\text { dysfunction, such as } \\
\text { cytokine/chemokines } \\
\text { (IL-6, IL-8, TNF etc.), } \\
\text { inflammatory cell } \\
\text { surface markers, } \\
\text { endothelia stress } \\
\text { response marker, and } \\
\text { acute phase reactants, } \\
\text { etc. }\end{array}$ & [103] \\
\hline Multibiomarkesr & $\begin{array}{l}\text { Novel panel } \\
\text { markers of septic } \\
\text { acute kidney } \\
\text { injury. }\end{array}$ & $\begin{array}{l}\text { A multibiomarker- } \\
\text { based model to } \\
\text { estimate risk of septic } \\
\text { acute kidney injury in } \\
\text { pts with septic shock. }\end{array}$ & $\begin{array}{l}\text { Serum protein septic } \\
\text { biomarkers }\end{array}$ & No & No & $\begin{array}{l}\text { Potential } \\
\text { therapeutic } \\
\text { intervention. }\end{array}$ & $\begin{array}{l}\text { In pts with septic } \\
\text { shock, sera obtained } \\
\text { within24 hrs and } \\
3 \text { days after septic } \\
\text { shock. An excellent } \\
\text { markers: The decision } \\
\text { tree (AUC-ROC = } 0.95 \\
\text { or } 0.83 \text { ) indicates that } \\
\text { the tree was superior } \\
\text { to day } 1 \text { septic acute } \\
\text { kidney injury status } \\
\text { alone for estimating } \\
\text { day } 3 \text { septic acute } \\
\text { kidney injury risk. } \\
\text { Note: Decision tree } \\
\text { is acute kidney injury } \\
\text { network scheme. }\end{array}$ & [104] \\
\hline $\begin{array}{l}\text { Presepsin } \\
\text { (sCD14-ST) }\end{array}$ & $\begin{array}{l}\text { Candidate } \\
\text { surrogate marker } \\
\text { of type } 5 \text { CRS }\end{array}$ & $\begin{array}{l}\text { Sepsis is a systemic } \\
\text { inflammatory } \\
\text { response syndrome. } \\
\text { It usually evolves } \\
\text { multiple organ } \\
\text { dysfunction and } \\
\text { failure. SCD14-ST } \\
\text { is released into the } \\
\text { circulation during } \\
\text { monocyte activation } \\
\text { upon recognition of } \\
\text { LPS from infectious } \\
\text { agents. }\end{array}$ & $\begin{array}{l}\text { Plasma (chemilu- } \\
\text { minescent enzyme } \\
\text { immunoassay, } \\
\text { PATHFAST prespsin, } \\
\text { Mitsubishi Chemical). }\end{array}$ & No & NO & $\begin{array}{l}\text { Potential guiding } \\
\text { therapy for pts with } \\
\text { sepsis. }\end{array}$ & $\begin{array}{l}\text { A candidate } \\
\text { surrogate prognostic } \\
\text { marker for mortality } \\
\text { prediction in pts with } \\
\text { severe sepsis or septic } \\
\text { shock (AUC -ROC= } \\
0.69,0.70 \text {, and } 0.74 \\
\text { on day } 1,2 \text {, and } \\
7 \text {, respectively, for } \\
\text { prognostic accuracy). }\end{array}$ & {$[105,106]$} \\
\hline
\end{tabular}


Citation: McCullough PA, Tumlin JA, Szerlip H, Vijayaraghavan K, Jyothinagaram S, et al. (2015) Cardiorenal Syndromes: Advances in Determining Diagnosis, Prognosis, and Therapy. J Cardiovasc Dis Diagn 3: 221. doi: 10.4172/2329-9517.1000221

\begin{tabular}{|c|c|c|c|c|c|c|c|c|}
\hline $\begin{array}{l}\text { Syndecan-1, } \\
\text { thrombomodulin, } \\
\text { protein C and FF }\end{array}$ & $\begin{array}{l}\text { Candidate } \\
\text { surrogate marker } \\
\text { of type } 5 \text { CRS }\end{array}$ & $\begin{array}{l}\text { Coagulopathy, } \\
\text { microcirculatory } \\
\text { failure, and } \\
\text { endothelial damage/ } \\
\text { activation are often } \\
\text { present in pts with } \\
\text { severe sepsis. } \\
\text { Endothelial damage } \\
\text { is intimately linked } \\
\text { to coagulopathy in } \\
\text { severe sepsis and } \\
\text { septic shock. Plasma } \\
\text { endothelial markers } \\
\text { (Syndecan-1, } \\
\text { thrombomodulin, } \\
\text { protein C) are } \\
\text { available for pts with } \\
\text { sepsis. }\end{array}$ & Plasma (ELISA) & No & No & $\begin{array}{l}\text { Clinically, } \\
\text { endothelial } \\
\text { protective } \\
\text { interventions } \\
\text { would be expected } \\
\text { to attenuate } \\
\text { sepsis-induced } \\
\text { hypocoagulability. }\end{array}$ & $\begin{array}{l}\text { A panel diagnostic } \\
\text { marker for coagulation } \\
\text { and fibriolysis in } \\
\text { pts with severe } \\
\text { sepsis. Plasma } \\
\text { levels of Syndecan-1, } \\
\text { thrombomodulin, } \\
\text { protein C) were } \\
\text { independently } \\
\text { associated whole blood } \\
\text { hypocoagulability, but } \\
\text { fibrinolysis (FF) was } \\
\text { inversely associated } \\
\text { with syndecan-1 } \\
\text { quarties. }\end{array}$ & [107] \\
\hline
\end{tabular}

† This table is not intended to be exhaustive.

*For biomarkers from preclinical biomarkers translated into clinical setting, several processes are needed, including bridging preclinical biomarkers to clinical biomarkers, validation of the biomarker, transplantation application of preclinical biomarkers into clinical setting, and clinical qualification.

Biomarker abbreviations

Alb = albumin; BNP = B-type natriuretic peptide; FF = functional fibrinogen; IL-6= interleukin 6; IL-8 = interleukin 8; sCD14-ST= soluble CD14 subtype (presepsin); TNF= tumor necrosis factor.

Other abbreviations

AUC = area under a ROC curve; CAD = coronary artery disease; CRS = cardiorenal syndrome; ELISA = enzyme-linked immunosorbent assay; eGFR = estimated glomerular filtration rate; CRS = cardiorenal syndrome; LBP = lipopolysacchride binding protein; LPS = lipopolysaccharide; pts = Patients; ROC = receiver-operating characteristic; UACR = urine albumin/creatinine ratio.

Table $3^{+}$: Clinical biomarkers* used or proposed for type 5 cardiorenal syndrome.

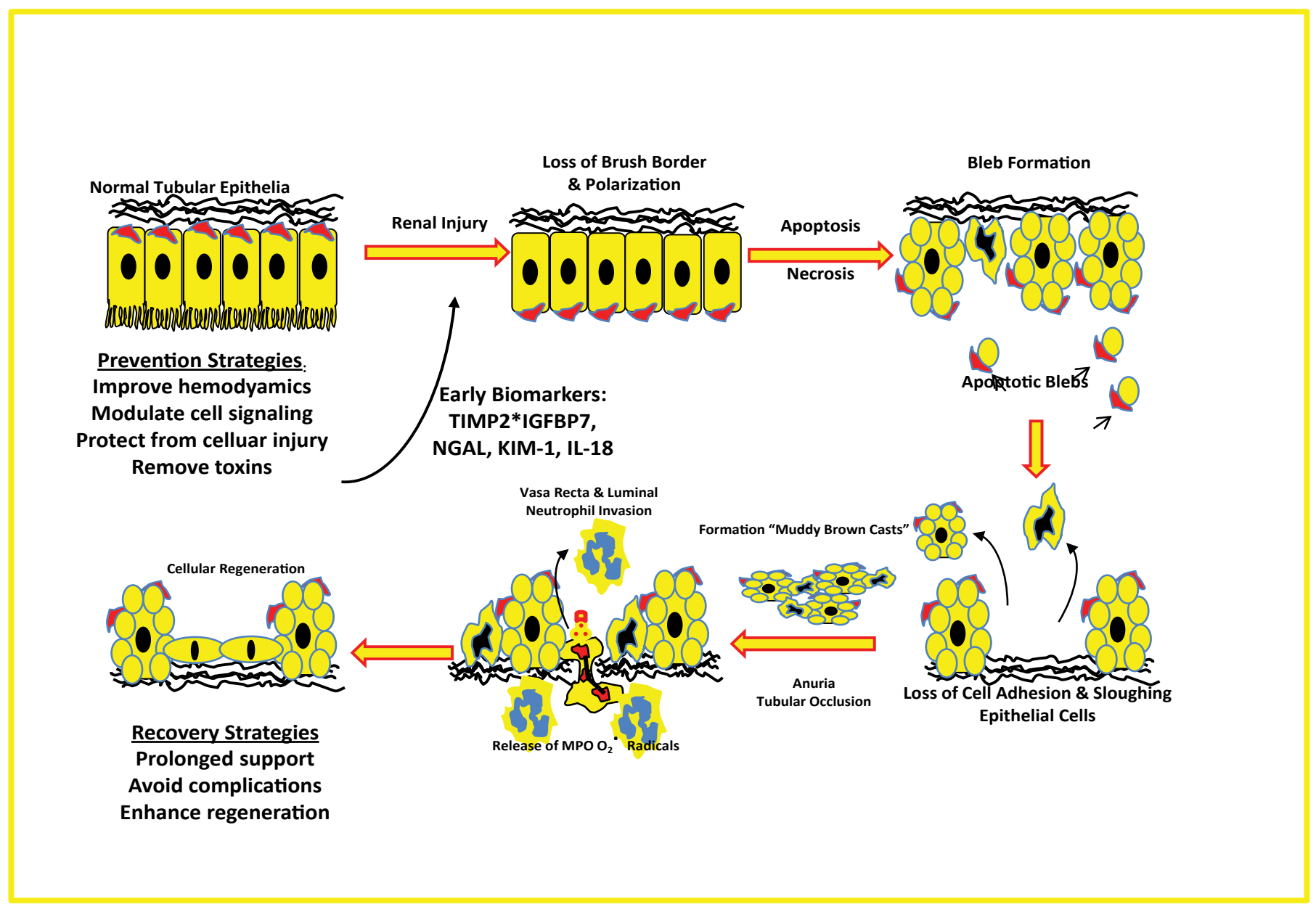

Figure 7: Pathogenesis of tubular cell injury. 


\begin{tabular}{|c|c|c|}
\hline CHALLENGES & CONSEQUENCES & POTENTIAL SOLUTIONS \\
\hline $\begin{array}{l}\text { Lack of CRS-specific symptoms and reliable } \\
\text { intermediate markers of disease progression }\end{array}$ & $\begin{array}{l}\text { - Reliance on binary "hard" endpoints } \\
\text { - Obligatory large, expensive, long-term trials, } \\
\text { not feasible for many potential treatments }\end{array}$ & $\begin{array}{l}\text { - Develop reliable intermediate outcomes, } \\
\text { clearly linked to hard endpoints } \\
\text { - Smaller, more focused trials }\end{array}$ \\
\hline $\begin{array}{l}\text { Focus on average treatment effects to } \\
\text { determine if intervention works }\end{array}$ & $\begin{array}{l}\text { - Failure to provide personalized treatment } \\
\text { approach, so patients most likely to benefit } \\
\text { are also most likely to be treated }\end{array}$ & $\begin{array}{l}\text { - Rigorous assessment of treatment } \\
\text { heterogeneity (benefit and risk) } \\
\text { - Targeting interventions to patients most } \\
\text { likely to benefit }\end{array}$ \\
\hline Highly selective patient populations & - Lack of generalizability & $\begin{array}{l}\text { - Long-term registries to monitor benefits and } \\
\text { risks in "real-world" clinical practice }\end{array}$ \\
\hline
\end{tabular}

Figure 8: Change in priorities needed in future studies to help advance CRS.

\section{Summary}

In the past 20 years, we have witnessed progress in common understanding and agreement in the concepts and definitions of acute myocardial infarction, heart failure, CKD, and CRS. A unform lexicon has aided patients, clinicians, and researchers as they deal with the issues of acute and chronic heart and kidney disease. The future is bright in terms of diagnostic and therapeutic strategies that will lead to prolonged quantity and quality of life for patients with these common conditions.

\section{References}

1. McCullough PA, Wolyn R, Rocher LL, Levin RN, O'Neill WW (1997) Acute renal failure after coronary intervention: incidence, risk factors, and relationship to mortality. Am J Med 103: 368-375.

2. McCullough PA, Soman SS, Shah SS, Smith ST, Marks KR, et al. (2000) Risks associated with renal dysfunction in patients in the coronary care unit. $\mathrm{J}$ Am Coll Cardiol 36: 679-684

3. Beattie JN, Soman SS, Sandberg KR, Yee J, Borzak S, et al. (2001) Determinants of mortality after myocardial infarction in patients with advanced renal dysfunction. Am J Kidney Dis 37: 1191-1200.

4. McCullough PA (2002) Cardiorenal risk: an important clinical intersection. Rev Cardiovasc Med 3: 71-76.

5. McCullough PA (2002) Scope of cardiovascular complications in patients with kidney disease. Ethn Dis 12: S3-44-8.

6. Levin A, Stevens L, McCullough PA (2002) Cardiovascular disease and the kidney. Tracking a killer in chronic kidney disease. Postgrad Med 111: 53-60.

7. McCullough PA, Ahmad A (2011) Cardiorenal syndromes. World J Cardiol 3: $1-9$

8. McCullough PA (2004) Cardiovascular risk reduction and preservation of rena function in the early nephropathy patient. Adv Chronic Kidney Dis 11: 184-191.

9. Khouri Y, Steigerwalt SP, Alsamara M, McCullough PA (2011) What is the ideal blood pressure goal for patients with stage III or higher chronic kidney disease? Curr Cardiol Rep 13: 492-501.

10. https://clinicaltrials.gov/ct2/show/NCT01206062

11. Riveline JP, Danchin N, Ledru F, Varroud-Vial M, Charpentier G (2003) Sulfonylureas and cardiovascular effects: from experimental data to clinical use. Available data in humans and clinical applications. Diabetes Metab 29: 207-222.

12. Stafylas PC, Sarafidis PA, Lasaridis AN (2009) The controversial effects of thiazolidinediones on cardiovascular morbidity and mortality. Int J Cardiol 131 298-304.

13. Wu S, Hopper I, Skiba M, Krum H (2014) Dipeptidyl peptidase-4 inhibitors and cardiovascular outcomes: meta-analysis of randomized clinical trials with 55,141 participants. Cardiovasc Ther 32: 147-158.

14. Gilbert RE (2014) SGLT-2 inhibition in patients with kidney disease. Diabetes Metab 40: S23-27.
15. Ridderstrale M, Svaerd R, Zeller C, Kim G, Woerle HJ, et al. EMPA-REG $\mathrm{H} 2 \mathrm{H}-\mathrm{SU}$ trial investigators. Rationale, design and baseline characteristics of a 4-year (208-week) phase III trial of empagliflozin, an SGLT2 inhibitor, versus glimepiride as add-on to metformin in patients with type 2 diabetes mellitus with insufficient glycemic control. Cardiovasc Diabetol 12: 129.

16. Heerspink HJ, Gao P, de Zeeuw D, Clase C, Dagenais GR, et al. (2014) The effect of ramipril and telmisartan on serum potassium and its association with cardiovascular and renal events: results from the ON TARGET trial. Eur J Prev Cardiol 21: 299-309.

17. Parving HH, Brenner BM, McMurray JJ, de Zeeuw D, Haffner SM, et al. (2012) Cardiorenal end points in a trial of aliskiren for type 2 diabetes. $\mathrm{N}$ Engl $\mathrm{J}$ Med 367: 2204-2213.

18. Alfie J, Aparicio LS, Waisman GD (2011) Current strategies to achieve further cardiac and renal protection through enhanced renin-angiotensin-aldosterone system inhibition. Rev Recent Clin Trials 6: 134-146.

19. Abbas S, Ihle P, Harder S, Schubert I (2015) Risk of hyperkalemia and combined use of spironolactone and long-term ACE inhibitor/angiotensin receptor blocker therapy in heart failure using real-life data: a population- and insurance-based cohort. Pharmacoepidemiol Drug Saf 24: 406-413.

20. Charytan DM, Fishbane S, Malyszko J, McCullough PA, Goldsmith D (2015) Cardiorenal Syndrome and the Role of the Bone-Mineral Axis and Anemia. Am J Kidney Dis 66: 196-205.

21. McCullough PA, Barnhart HX, Inrig JK, Reddan D, Sapp S, et al. (2013) Cardiovascular toxicity of epoetin-alfa in patients with chronic kidney disease. Am J Nephrol 37: 549-558.

22. McCullough PA Ali S (2012) Cardiac and renal function in patients with type 2 diabetes who have chronic kidney disease: potential effects of bardoxolone methyl. Drug Des Devel Ther 6: 141-149.

23. Chin MP, Wrolstad D, Bakris GL, Chertow GM, de Zeeuw D, et al. (2014) Risk factors for heart failure in patients with type 2 diabetes mellitus and stage 4 chronic kidney disease treated with bardoxolone methyl. J Card Fail 20: 953958.

24. Study of Diabetic Nephropathy with Atrasentan (SONAR) ClinicalTrials.gov Identifier: NCT01858532

25. McCullough PA, Kuncheria J, Mathur VS (2003) Diagnostic and therapeutic utility of B-type natriuretic peptide in patients with renal insufficiency and decompensated heart failure. Rev Cardiovasc Med 7: S3-S12.

26. McCullough PA, Sandberg KR (2003) B-type natriuretic peptide and renal disease. Heart Fail Rev 8: 355-358.

27. McCullough PA, Jefferies JL (2015) Novel markers and therapies for patients with acute heart failure and renal dysfunction. Am J Med 128: 312.

28. Hundae A, McCullough PA (2014) Cardiac and renal fibrosis in chronic cardiorenal syndromes. Nephron Clin Pract 127: 106-112.

29. McCullough PA, Olobatoke A, Vanhecke TE (2011) Galectin-3: a novel blood test for the evaluation and management of patients with heart failure. Rev Cardiovasc Med 12: 200-210.

30. Tumlin JA, Costanzo MR, Chawla LS, Herzog CA, Kellum JA, et al 
Citation: McCullough PA, Tumlin JA, Szerlip H, Vijayaraghavan K, Jyothinagaram S, et al. (2015) Cardiorenal Syndromes: Advances in Determining Diagnosis, Prognosis, and Therapy. J Cardiovasc Dis Diagn 3: 221. doi: 10.4172/2329-9517.1000221

Page 27 of 28

(2013) Cardiorenal syndrome type 4: insights on clinical presentation and pathophysiology from the eleventh consensus conference of the Acute Dialysis Quality Initiative (ADQI). Contrib Nephrol 182: 158-173.

31. McCullough PA (2014) Practical experience using galectin-3 in heart failure. Clin Chem Lab Med 52: 1425-1431.

32. Yancy CW, Jessup M, Bozkurt B, Butler J, Casey DE Jr, et al. (2013) American College of Cardiology Foundation; American Heart Association Task Force on Practice Guidelines. 2013 ACCF/AHA guideline for the management of heart failure: a report of the American College of Cardiology Foundation/American Heart Association Task Force on Practice Guidelines. J Am Coll Cardiol 62 e147-239.

33. Levey AS, Inker LA, Matsushita K, Greene T, Willis K, et al. (2014) GFR decline as an end point for clinical trials in CKD: a scientific workshop sponsored by the National Kidney Foundation and the US Food and Drug Administration. Am J Kidney Dis 64: 821-835.

34. Lambers Heerspink HJ, Kröpelin TF, Hoekman J, de Zeeuw D; Reducing Albuminuria as Surrogate Endpoint (REASSURE) Consortium (2015) Drug-Induced Reduction in Albuminuria Is Associated with Subsequent Renoprotection: A Meta-Analysis. J Am Soc Nephrol 26: 2055-2064.

35. Study Of Diabetic Nephropathy With Atrasentan (SONAR), https://clinicaltrials gov/ct2/show/NCT01858532

36. McCullough PA, Beaver TM, Bennett-Guerrero E, Emmett M, Fonarow GC et al. (2014) Acute and chronic cardiovascular effects of hyperkalemia: new insights into prevention and clinical management. Rev Cardiovasc Med 15: 11 23.

37. Buysse JM, Huang IZ, Pitt B (2012) PEARL-HF: prevention of hyperkalemia in patients with heart failure using a novel polymeric potassium binder, RLY5016. Future Cardiol 8: 17-28

38. Weir MR, Bakris GL, Bushinsky DA, Mayo MR, Garza D, et al. (2015) Patiromer in patients with kidney disease and hyperkalemia receiving RAAS inhibitors. N Engl J Med 372: 211-221.

39. Packham DK, Rasmussen HS, Lavin PT, El-Shahawy MA, Roger SD, et al (2015) Sodium zirconium cyclosilicate in hyperkalemia. N Engl J Med 372: 222 231.

40. Kosiborod M, Rasmussen HS, Lavin P, Qunibi WY, Spinowitz B, et al. Effect of sodium zirconium cyclosilicate on potassium lowering for 28 days among outpatients with hyperkalemia: the HARMONIZE randomized clinical trial. JAMA 312: 2223-2233.

41. McCullough PA (2014) Calling for targeted trials in cardiorenal syndromes. Am J Kidney Dis 64: 10-12.

42. Schmieder RE, Mitrovic V, Hengstenberg C (2015) Renal impairment and worsening of renal function in acute heart failure: can new therapies help? The potential role of serelaxin. Clin Res Cardiol 104: 621-631.

43. Givertz MM, Teerlink JR, Albert NM, Westlake Canary CA, Collins SP, et al (2013) Acute decompensated heart failure: update on new and emerging evidence and directions for future research. J Card Fail 19: 371-389.

44. Hauptman PJ, Mikolajczak P, George A, Mohr CJ, Hoover R, et al. (2006) Chronic inotropic therapy in end-stage heart failure. Am Heart J 152: 1096.

45. Koyner JL, Davison DL, Brasha-Mitchell E, Chalikonda DM, Arthur JM, et al. (2015) Furosemide Stress Test and Biomarkers for the Prediction of AKI Severity. J Am Soc Nephrol 26: 2023-2031.

46. McCullough PA, Shaw AD, Haase M, Bouchard J, Waikar SS, et al. (2013) Diagnosis of acute kidney injury using functional and injury biomarkers: workgroup statements from the tenth Acute Dialysis Quality Initiative Consensus Conference. Contrib Nephrol 182: 13-29.

47. Kashani K, Al-Khafaji A, Ardiles T, Artigas A, Bagshaw SM, et al. (2013) Discovery and validation of cell cycle arrest biomarkers in human acute kidney injury. Crit Care 17: R25

48. Edwards JK (2015) Biomarkers: How precise is NephroCheck®? Nat Rev Nephrol 11: 127

49. Satirapoj B, Siritaweesuk N, Supasyndh O (2014) Urinary angiotensinogen as a potential biomarker of diabetic nephropathy. Clin Kidney J 7: 354-360.

50. McCullough PA, Bouchard J, Waikar SS, Siew ED, Endre ZH, et al Implementation of novel biomarkers in the diagnosis, prognosis, and management of acute kidney injury: executive summary from the tenth consensus conference of the Acute Dialysis Quality Initiative (ADQI). Contrib Nephrol 182: 5-12

51. Sharma A, Mucino MJ, Ronco C (2014) Renal functional reserve and rena recovery after acute kidney injury. Nephron Clin Pract 127: 94-100.

52. D’Marco L, Bellasi A, Raggi P (2015) cardiovascular biomarkers in chronic kidney disases: stage on current research and clinical applicability. DisMarkers.

53. Stacy SR, Suarez-Cuervo C, Berger Z, Wilson LM, Yeh H-C, et al. (2014) Role of troponin in patients with chronic kidney disease and suspected acute coronary syndrome. Ann Inter Med 161: 502-512.

54. Bansal N, Anderson AH, Yang W, Christenson RH, deFilipp CR, et al. (2014) High-sensitivity troponin $\mathrm{T}$ and $\mathrm{N}$-terminal Pro-B-type natriuretic peptide (NTproBNP) and risk of incident heart failure in patients with CKD: the Chronic Renal Insufficiency Cohort (CRIC) study. J Am Soc Nephrol 26: 946-956.

55. Pruett AE, Lee AK, Patterson JH, Schwartz TA, Glotzer JM, et al. (2015) Evolution of biomarker guided therapy for heart failure: current concepts and trial evidence. Curr Cardiol Rev 11: 80-89.

56. Lok DJ, Van Der Meer P, de la Porte PW, Lipsic E, Van Wijngaarden J, et al. (2010) Prognostic value of galectin-3, a novel marker of fibrosis, in patients with chronic heart failure: data from the DEAL-HF study. Clin Res Cardiol 99 323-328.

57. Zhu ZD, Sun T (2015) Association between growth differentiation factor-15 and chronic heart failure in coronary atherosclerosis patients. Genet Mol Res 14 2225-2233.

58. Bucholz EM, Whitlock RP, Zappitelli M, Devarajan P, Eikelboom J, et al. (2015) Cardaic biomarkers and acute kidney injury after cardiac surgery. Pediatrics 135: e945-956.

59. Piper SE, Sherwood RA, Amin-Youssef GF, Shah AM, McDonagh TA (2015) Serial soluble ST2 for the monitoring of pharmacologically optimised chronic stable heart failure. Int J Cardiol 178: 284-291.

60. Bayes-Genis A, Zhang Y, Ky B (2015) ST2 and patient prognosis in chronic heart failure. Am J Cardiol 115: 64B-9B

61. Bayes-Genis A, Richards AM, Maisel AS, Mueller C, Ky B (2015) Multimarker testing with ST2 in chronic heart failure. Am J Cardiol 115: 76B-80B.

62. Januzzi JL, Pascual-Figal D, Daniels LB (2015) ST2 testing for chronic heart failure therapy monitoring: the International ST2 Consensus Panel. Am J Cardiol 115: 70B-5B

63. Takada T, Kodera Y, Matsubara M, Kawashima Y, Maeda T, et al. (2013) Serum monomeric $\alpha 2$-macroglobulin as a clinical biomarker in diabetes. Atherosclerosis 228: $270-276$

64. Annapoorani P, Dhandapany PS, Sadayappan S, Ramasamy S, Rathinave A, et al. (2006) Cardiac isoform of alpha-2 macroglobulin--a new biomarker for myocardial infarcted diabetic patients. Atherosclerosis 186: 173-176.

65. Bonomini F, Foglio E, Rodella LF, Rezzani R (2010) Clinical biomarkers in kidney diseases. Front Biosci (Schol Ed) 2: 591-615

66. lacoviello M, Leone M, Antoncecchi V, Ciccone MM (2015) Evaluation of chronic kidney disease in chronic heart failure: From biomarkers to arterial renal resistances. World J Clin Cases 3: 10-19.

67. Fukuda A, Wickman LT, Venkatareddy MP, Wang SQ, Chowdhury MA, et al. (2012) Urine podocin:nephrin mRNA ratio (PNR) as a podocyte stress biomarker. Nephrol Dial Transplant 27: 4079-4087.

68. Sabino AR, Teixeira Vde P, Nishida SK, Sass N, Mansur JB, et al. (2013) Detection of podocyturia in patients with lupus nephritis. J Bras Nefrol 35: 252 258

69. Wang P, Li M, Liu Q, Chen B, Ji Z (2015) Detection of urinary podocytes and nephrin as markers for children with glomerular diseases. Exp Biol Med (Maywood) 240: 169-174

70. Sabbisetti VS, Waikar SS, Antoine DJ, Smiles A, Wang C, et al. (2014) Blood kidney injury molecule-1 is a biomarker of acute and chronic kidney injury and predicts progression to ESRD in type I diabetes. J Am Soc Nephrol 25: 2177 2186.

71. Du TY, Luo HM, Qin HC, Wang F, Wang Q, et al. (2013) Circulating serum trefoil factor 3 (TFF3) is dramatically increased in chronic kidney disease. PLoS One 8: e80271. 
Citation: McCullough PA, Tumlin JA, Szerlip H, Vijayaraghavan K, Jyothinagaram S, et al. (2015) Cardiorenal Syndromes: Advances in Determining Diagnosis, Prognosis, and Therapy. J Cardiovasc Dis Diagn 3: 221. doi: 10.4172/2329-9517.1000221

72. Agarwal R, Duffin KL, Laska DA, Voelker JR, Breyer MD, et al. (2014) A prospective study of multiple protein biomarkers to predict progression in diabetic chronic kidney disease. Nephrol Dial Transplant 29: 2293-2302.

73. Gordin D, Forsblom C, Pandurn NM, Thomas MC, Bjerre M, et al. (2014) Ostepontin is a strong predictor of incident diabetic nephropathy, cardiovascular disease, and all-cause mortality in patients with type 1 diabetes. Diabetes Care 37: 2593-2600.

74. Storm T, Tranebjærg L, Frykholm C, Birn H, Verroust PJ, et al. Renal phenotypic investigations of megalin-deficient patients: novel insight into tubular proteinuria and albumin filtration. Nephrol Dial Tranplant 28: 585-591.

75. Zhou J, Chen Y, Liu Y, Shi S, Wang S, et al. (2013) Urinary uromodulin excretion predicts progression of chronic kidney disease resulting from IgA nephropathy. PLoS One 8: e71023.

76. Zhou H, Cheruvanky A, Hu X, Matsumoto T, Hiramatsu N, et al. (2008) Urinary exosomal transcription factors, a new class of biomarkers for renal disease. Kidney Int 74: 613-621.

77. Herman E, Knapton A, Zhang J, Estis J, Todd J, et al. (2014) The utility of serum biomarkers to detect myocardial alterations induced by Imatinib in rats. Pharmacol Res Perspect 2: e00015.

78. Wallace KB, Hausner E, Herman E, Holt GD, MacGregor JT, et al. (2004) Serum troponins as biomarkers of drug-induced cardiac toxicity. Toxicol Pathol 32: 106-121.

79. Palazzuoli A, McCullough PA, Ronco C, Nuti R (2015) Kidney disease in heart failure: the importance of novel biomarkers for type 1 cardio-renal syndrome detection. Intern Emerg Med 10: 543-554.

80. Pruett AE, Lee AK, Patterson JH, Schwartz TA, Glotzer JM, et al. (2015) Evolution of biomarker guided therapy for heart failure: current concepts and trial evidence. Curr Cardiol Rev 11: 80-89.

81. de Boer RA, Lok DJ, Jaarsma T, van der Meer P, Voors AA, et al. (2011) Predictive value of plasma galectin-3 levels in heart failure with reduced and preserved ejection fraction. Ann Med 43: 60-68.

82. van Kimmenade RR, Januzzi JL Jr, Ellinor PT, Sharma UC, Bakker JA, et al (2006) Utility of amino-terminal pro-brain natriuretic peptide, galectin-3, and apelin for the evaluation of patients with acute heart failure. J Am Coll Cardio 48: $1217-1224$.

83. McCullough PA, Nowak RM, McCord J, Hollander JE, Herrmann HC, et al. (2002) B-type natriuretic peptide and clinical judgment in emergency diagnosis of heart failure: analysis from Breathing Not Properly (BNP) Multinational Study. Circulation 106: 416-422.

84. Bucholz EM, Whitlock RP, Zappitelli M, Devarajan P, Eikelboom J, et al. (2015) Cardiac biomarkers and acute kidney injury after cardiac surgery. Pediatrics 135: e945-956.

85. Vianello A, Caponi L, Galetta F, Franzoni F, Taddei M, et al. (2015) B2 Microglobulin and TIMP1 Are Linked Together in Cardiorenal Remodeling and Failure. Cardiorenal Med 5: 1-11.

86. Zakeri R, Sangaralingham SJ, Sandberg SM, Heublein DM, Scott CG, et al. (2013) Urinary C-type natriuretic peptide: a new heart failure biomarker. JACC Heart Fail 1: 170-177.

87. Zakeri R, Burnett JC Jr, Sangaralingham SJ (2015) Urinary C-type natriuretic peptide: an emerging biomarker for heart failure and renal remodeling. Clin Chim Acta 443: 108-113.

88. Shin SJ, Wen JD, Lee YJ, Chen IH, Tsai JH (1998) Increased C-type natriuretic peptide mRNA expression in the kidney of diabetic rats. J Endocrinol 158: 35 42.

89. Fuchs TC, Hewitt $P$ (2011) Preclinical perspective of urinary biomarkers for the detection of nephrotoxicity: what we know and what we need to know. Biomark Med 5: 763-779.
90. Vaidya VS, Ferguson MA, Bonventre JV (2008) Biomarkers of acute kidney injury. Annu Rev Pharmacol Toxicol 48: 463-493.

91. Bouquegneau A, Krzesinski JM, Delanaye P, Cavalier E (2015) Biomarkers and physiopathology in the cardiorenal syndrome. Clin Chim Acta 443: 100 107.

92. Vaidya VS, Waikar SS, Ferguson MA, Collings FB, Sunderland K, et al. (2008) Urinary biomarkers for sensitive and specific detection of acute kidney injury in humans. Clin Transl Sci 1: 200-208.

93. Westhuyzen J, Endre ZH, Reece G, Reith DM, Saltissi D, et al. (2003) Measurement of tubular enzymuria facilitates early detection of acute renal impairment in the intensive care unit. Nephrol Dial Transplant 18: 543-551.

94. Adiyanti SS, Loho T (2012) Acute Kidney Injury (AKI) biomarker. Acta Med Indones 44: 246-255.

95. Takashi M, Zhu Y, Miyake K, Kato K (1996) Urinary 28-kD calbindin-D as a new marker for damage to distal renal tubules caused by cisplatin-based chemotherapy. Urol Int 56: 174-179.

96. Kashani K, Al-Khafaji A, Ardiles T, Artigas A, Bagshaw SM, et al. Discovery and validation of cell-cycle arrest biomarkers in human acute kidney injury. Crit Care 6: 17.

97. Bihorac A, Chawla LS, Shaw AD, Al-Khafaji A, Davison DL, et al. (2014 Validation of cell-cycle arrest biomarkers for acute kidney injury using clinical adjudication. Am J Respir Crit Care Med 189: 932-939.

98. Gocze I, Koch M, Renner P, Zeman F, Graf BM, et al. (2015) Urinary biomarkers TIMP-2 and IGFBP7 early predict acute kidney injury after major surgery. PLoS One 10: e0120863.

99. Meersch M, Schmidt C, Van Aken H, Martens S, Rossaint J, et al. (2014) Urinary TIMP-2 and IGFBP7 as early biomarkers of acute kidney injury and renal recovery following cardiac surgery. PLoS One 9: e93460.

100. Virzi GM, Clementi A, de Cal M, Brocca A, Day S, et al. (2015) oxidative stress: dual pathway induction in cardiarenal syndrome type 1 pathogenesis. Oxidative Medicone \& Cellular Longevity.

101. Yang L, Brooks CR, Xiao S, Sabbisetti V, Yeung MY, et al. (2015) KIM-1mediated phagocytosis reduces acute injury to the kidney. J Clin Invest 125 1620-1636.

102. Hashimoto J, Ito S (2014) Central pulse pressure links microalbuminuria with plasma B-type natriuretic peptide elevation: causal implication for cardiorenal syndrome in hypertension. J Hypertens 32: 1665-1671.

103. Mehta RA, Rabb H, Shaw AD, Singbartl K, Ronco C, et al. Cardiorenal syndrome type 5: clinical presentation, pathophysiology and management stragies from the eleventh consensus conference of the acute dialysis quality initiative (ADQI). Contrib Nephrol 182: 172-194.

104. Wong HR, Cvijanovich NZ, Anas N, Allen GL, Thomas NJ, et al. (2015) A Multibiomarker-Based Model for Estimating the Risk of Septic Acute Kidney Injury. Crit Care Med 43: 1646-1653.

105. Masson S, Caironi P, Spanuth E, Thomae R, Panigada M, et al. (2014) Presepsin (soluble CD14 subtype) and procalcitonin levels for mortality prediction in sepsis: data from the Albumin Italian Outcome Sepsis trial. Crit Care 18: R6.

106.Zou Q, Wen W, Zhang XC (2014) Presepsin as a novel sepsis biomarker World J Emerg Med 5: 16-19.

107. Ostrowski SR, Haase N, Müller RB, Møller MH, Pott FC, et al. (2015) Association between biomarkers of endothelial injury and hypocoagulability in patients with severe sepsis: a prospective study. Crit Care 19: 191. 